\title{
Why is there no Coastal Cordillera at the Arica Bend
}

\section{(Western Central Andes)?}

\author{
Andrea Madella ${ }^{1 *}$, Romain Delunel $^{1}$, Laurence Audin ${ }^{2}$, Fritz Schlunegger $^{1}$ \\ ${ }^{1}$ Institut für Geologie, Universität Bern, Baltzerstrasse 1+3, CH-3012 Bern \\ ${ }^{2}$ Institut des Sciences de la Terre, CNRS, IRD, Université Joseph Fourier, 1381, rue de la \\ Piscine 38400 Saint-Martin d'Hères, France
}

* Corresponding author: Andrea Madella, andrea.madella@geo.unibe.ch

\begin{abstract}
The architecture of the Western Andes is remarkably constant between southern Peru and northern Chile. An exception, however, is present near Arica at $18^{\circ} \mathrm{S}$, where the Andes change their strike direction by ca. $50^{\circ}$ and the Coastal Cordillera is absent over an alongstrike width of $50 \mathrm{~km}$. Although this feature has been mentioned in several previous studies, no effort has been made yet to describe and explain this peculiar morphology of the Western Central Andean forearc. Here, we propose a large-scale model to explain the Myr-long low uplift rate of the Arica Bend concerning seismic coupling and continental wedge-top basin evolution. New geomorphic and sedimentologic data are integrated with seismicity and

This article has been accepted for publication and undergone full peer review but has not been through the copyediting, typesetting, pagination and proofreading process, which may lead to differences between this version and the Version of Record. Please cite this article as doi: $10.1111 /$ bre. 12218

This article is protected by copyright. All rights reserved.
\end{abstract}


structural data from the literature to interpret the post-Oligocene pattern of uplift, erosion, and sediment transport to the trench. Results show that the Arica Bend has been marked by exceptionally low coastal uplift rates over post-Oligocene timescales. In addition, this uplift anomaly at the Arica Bend correlates with relatively high sediment discharge to the corresponding trench segment since late Oligocene time. We interpret that before $25 \mathrm{Ma}$, the forming seaward concavity of the subduction zone induced trench-parallel extension at the curvature apex of the overriding forearc. The subsequent low uplift rate would have then triggered a feedback mechanism, where the interplay between relatively-low interplate friction, low coastal uplift and relatively-high sediment discharge favored Myr-long relative subsidence at the Arica Bend, in contrast to Myr-long uplift of the Coastal Cordillera north and south of it.

Keywords: northern Chile, southern Peru, Coastal Cordillera, coastal uplift, seismic coupling, trench sedimentation, Andes.

\section{(A) 1. INTRODUCTION}

The western Andean margin has formed through the subduction of the Nazca oceanic plate beneath the South American continental plate since late Cretaceous (e.g GregoryWodzicki, 2000). The strike of this subduction zone parallels the mountain range (Fig.1). Between $17^{\circ}-20^{\circ} \mathrm{S}$ the Andes feature a remarkable change in the strike direction by $50^{\circ}$ from NW-SE to N-S, thereby marking a distinct deflection of the coastline. This sector of the Western Central Andes, which has been referred to as the "Arica Bend" in the literature (e.g. Wörner et al., 1988; Armijo \& Thiele, 1990), has been considered as one of the most conspicuous features of the mountain range. The Arica Bend presents particularities regarding (i) the arrangement of the litho-tectonic domains (Garcia \& Hérail, 2005), (ii) the 
absence of raised Quaternary terraces (Regard et al., 2010; Melnick, 2016) and (iii) the low historical seismicity (Comte \& Pardo, 1991). While the entire suite of trench-parallel domains including (from west to east): the Coastal Cordillera, the Central Depression, the Precordillera and the Western Cordillera (e.g. Charrier et al., 2013) are present along most of the Peruvian and Chilean Western Central Andes for a length of $>1000 \mathrm{~km}$, the Coastal Cordillera gradually descends in elevation from $>1000 \mathrm{~m}$ a.s.l. to sea-level as it approaches Arica from both sides of the bend (Fig.1). There, the along-strike profile of the Coastal Cordillera denotes a 300-km-wide and 1.4-km-deep depression with no coastal relief over a ca. 50-km-long segment between $18.2^{\circ} \mathrm{S}$ and $18.4^{\circ} \mathrm{S}$ (Fig.2).

A further particularity of the region concerns the seismicity. The entire margin between $15^{\circ}-24^{\circ} \mathrm{S}$ has been described as a locked plate-boundary (e.g. Comte \& Pardo, 1991), which means that plate convergence occurs almost exclusively during subduction earthquakes. Throughout the manuscript we will refer to the ratio between seismic slip and convergence rate with the expression "seismic coupling", as suggested by Wang \& Dixon (2004). In the Peru-Chile subduction zone, compressional stresses can accumulate for up to 200 year-long periods (interseismic) before a mega-thrust earthquake (coseismic) occurs. The seismogenic zone of the plate interface extends down to approximately $50 \mathrm{~km}$ in depth (Allmendinger et al., 2005a; Li et al., 2015) and is composed of an irregular ensemble of aseismic, conditionally stable and seismic patches (Lay et al., 2012). This complex pattern of seismic coupling implies that the seismic cycle occurs unevenly both along- and acrossstrike. Accordingly, a remaining locked patch of margin adjacent to recently ruptured segments is referred to as "seismic gap" (e.g. Thatcher, 1989), and it corresponds to the location where the next megathrust earthquake is expected to occur.

This article is protected by copyright. All rights reserved. 
In historical times, the Western Central Andean margin has repeatedly hosted several megathrust earthquakes such as, among many others, the $1868 \mathrm{M} 8.8$ northwest of Arica, the 1877 M 8.8 Iquique (Dorbath et al., 1990; Comte \& Pardo, 1991) and the recent 2001 M 8.4 southern Peru and 2014 M 8.2 Iquique slip events (e.g. Hayes et al., 2014). Nevertheless, whether or not these ruptures were able to propagate through the Arica Bend has remained a matter of debate (Hayes et al., 2014). It appears, in fact, that the plate interface at the Arica Bend has not experienced any historical mega-thrust earthquake (Dorbath et al., 1990) and that this particular segment generally has experienced a low seismicity. Moreover, as mentioned above, the corresponding coastal area has undergone no measurable Quaternary rock uplift, in contrast to the adjacent coastal regions north and south of it (Fig.2).

Crustal deformation in response to seismic cycles can be accomplished through an elastic or viscoelastic mechanism (e.g. Savage, 1983; Li et al., 2015). These end-member scenarios have been useful for studies addressing short timescales spanning several hundreds of years, when coseismic rebound equalizes interseismic deformation, whereas at the Myrscale, re-iterated small amounts of permanent deformation need to be accommodated by long-lived brittle structures (King et al., 1988). Throughout the manuscript we will use the term "long-term coupling" to refer to the fraction of convergence that is accommodated by permanent deformation within the forearc. A number of authors (Audin et al., 2008; Allmendinger \& González, 2010; Loveless et al., 2010; Victor et al., 2011; Binnie et al., 2016) showed that permanent deformation in response to subduction earthquakes can be observed in the Coastal Cordillera, and that the faults accommodating this deformation have most likely been active since late Neogene-Quaternary time. In addition, Melnick (2016) showed that Myr-long uplift of the Coastal Cordillera of both southern Peru and northern Chile might be linked with the occurrence of megathrust earthquakes straddling depth levels 
as deep as the Moho. Accordingly, these authors seem to suggest that the deformation of the coastal range might constitute the surface expression of processes acting at the plate interface.

In this paper, we test the hypothesis of whether the aforementioned along-strike differences in coastal uplift and seismicity could be related to characteristics of the subduction zone or the individual plates, such as: (i) the topography of the subducting plate (Hampel, 2002; Kukowski \& Oncken, 2006; Contreras-Reyes \& Carrizo, 2011), (ii) the obliquity of subduction (Liu et al., 1995; Hampel et al., 2004; Audin et al., 2008), (iii) the curvature of the margin (Bonnardot et al., 2008; Boutelier \& Oncken, 2010), or alternatively (iv) along-strike differences in trench sedimentation and related friction at the plate interface (Lamb \& Davis, 2003; von Huene \& Ranero, 2003; Clift \& Vannucchi, 2004; Oncken et al., 2006). We will show (see discussion) that hypotheses (i), (ii) and (iii), which have already been discussed in the articles cited above, do not effectively explain the along-strike differences in long-term coupling and coastal uplift observed along the Arica Bend. We therefore investigate the validity of hypothesis (iv), concerning possible feedback mechanisms between trench sedimentation, seismic coupling and crustal deformation at a smaller time and spatial scale than has previously been done (Lamb \& Davis, 2003). In particular, we will illustrate that the supply of sediment to the Pacific Ocean near Arica has been larger than in the sections to the north and south for the past tens of millions of years. This observation, contextualized in the growing subduction curvature, will allow us to develop a conceptual model that may explain the occurrence of a local decrease in seismic coupling ratio and, hence, the absence of crustal deformation and surface uplift in the coastal region of Arica during the past millions of years. This work, in summary, represents a first attempt to address this poorly understood problem and relies on the compilation and reinterpretation of existing stratigraphic and geodynamic data and new mapping and sedimentological data.

This article is protected by copyright. All rights reserved. 
(A)

\section{SETTING}

\section{(B) 2.1. Stratigraphy and landscape evolution}

The basement of the Western Central Andean forearc is an ensemble of magmatic and sedimentary rocks that were emplaced during eastward migration of the volcanic arc throughout Jurassic to Neogene time (Coira et al., 1982; Wörner et al., 2002; Armijo et al., 2015). Since at least the late Oligocene, the uplift of the Coastal Cordillera has formed accommodation space for a late Oligocene-Miocene period of continental sedimentation (Armijo et al, 2015 and references therein). In this time volcanoclastic alluvial and fluvial fans, pyroclastic mass-flows and fluvio-lacustrine sediments sourced in the uplifting Western Cordillera were deposited in the Central Depression east of the Coastal Cordillera, burying the basement with an unconformity (Tosdal et al., 1984; González et al., 2003; Armijo et al., 2015). The surface of these deposits forms the modern pediplains, or pampas, that extend laterally over hundreds of kilometers along strike and that link the Coastal Cordillera to the Precordillera. This latter domain represents an along-strike 20-30 km-wide range mostly formed of abandoned eroded volcanic edifices.

Despite similarities in their stratigraphic architecture, the categorization of the units in the Central Depression has been different on either side of the Arica Bend. The related units have been referred to as: Azapa (25-23 Ma), Oxaya (22.7-19.4 Ma) and El Diablo (17$11 \mathrm{Ma}$ ) formations in northern Chile, south of Arica (Wörner et al., 2002; Pinto et al., 2004; von Rotz et al., 2005; Wotzlaw et al., 2011; Jordan et al., 2014) and Moquegua C (34-25 Ma), Huaylillas (25.5-16.4 Ma) and Moquegua D (17-11 or possibly $8 \mathrm{Ma}$ ) formations in southern Peru, north of Arica (Roperch et al., 2006; Decou et al., 2011; Decou et al., 2013). The continental suite is generally $1100 \mathrm{~m}$ thick on both sides of the bend. It reaches a maximum thickness of ca. $1800 \mathrm{~m}$ below the Pampa del Tamarugal in northern Chile (Fig.1) (Hartley et al., 2000; Nester \& Jordan, 2012), from where it thins to a few hundreds of meters 
at most at the latitude of the Arica Bend (Uhlig, 1999). West of the Coastal Cordillera of southern Peru, between $16.25^{\circ}-17.15^{\circ} \mathrm{S}$, an up to $500 \mathrm{~m}$-thick late Oligocene to early Pliocene sedimentary suite has been referred to as the Camana formation (Alván \& von Eynatten, 2014) (Fig.3a). These deltaic and marine sediments, sourced mostly in the Coastal Cordillera, constitute the time-equivalent unit of the Moquegua C, Huaylillas and Moquegua D formations that are located in the Central Depression at the same latitude. South of $17.15^{\circ} \mathrm{S}$, the only documented deposits west of the Coastal Cordillera are the so-called "rasas" (uplifted Quaternary marine terraces) (Fig.3c) (Ortlieb, 1996; Regard et al., 2010). At the Arica Bend $\left(18.3^{\circ} \mathrm{S}\right)$, Kober et al. (2006) postulated that the system feeding the 17-11 (Jordan et al., 2014) to possibly 8 Ma-old El Diablo conglomerates (Von Rotz et al., 2005) has been open to the ocean throughout the depositional time of this unit (Fig.3b). This situation thus contrasts with the locations north and south of the Arica Bend, where most of the clastic suite was retained by the Coastal Cordillera (Fig.3) (Roperch et al., 2006; Jordan et al., 2014), as documented onlap relationships show (Schlunegger et al., 2010; Nester \& Jordan, 2012). The uplift of the Coastal Cordillera commenced at ca. $25 \mathrm{Ma}$, as inferred from the stratigraphy of its eastern flank (Wörner et al., 2002), and continued with rates in the order of $0.2 \mathrm{~mm} / \mathrm{y}$ during late Neogene-Quaternary time, as the morphology of its western flank suggests (Regard et al., 2010; Melnick, 2016). Indeed, these authors have shown that the steep coastal scarp and perched "rasas" are the result of wave erosion on an actively uplifting coast, modulated by sea-level oscillations.

Along the entire Western Central Andean forearc, volcanoclastic sedimentation was followed by regional monoclinal warping and canyon incision, during the late Miocene uplift of the western margin of the Altiplano (Wörner et al., 2002; Farías et al., 2005; von Rotz et al., 2005; Schildgen et al., 2007; Thouret et al., 2007; Charrier et al., 2013; Jordan et al., 2014; Armiijo et al., 2015). Whether the geodynamic process driving this event is related to 
mantle delamination or lower crustal flow is still a matter of debate (Garzione et al., 2006; Ghosh et al., 2006; Sempéré et al., 2006; Hartley et al., 2007; Garzione et al., 2007; Garzione et al., 2008; Garzione et al., 2014). However, it seems that this phase of monoclinal warping of the western Andean margin was rooted, and thus linked, to geodynamic processes within the domain of the Altiplano Plateau (Barnes et al., 2012; Whipple and Gasparini, 2014), causing a widespread uplift across the Central Andes. This phase of uplift and monoclinal warping might also have initiated the incision of the modern $>500$-m-deep valleys (e.g. Lluta, Azapa, Camarones, Caplina, Locumba) due to steepening of the forearc (Wörner et al., 2002; Kober et al., 2006; Schlunegger et al., 2010; García et al., 2011). Channel incision might have also been favoured by a slightly wetter phase during the Pliocene through larger runoff of the Andean streams (Ehlers and Poulsen, 2009; Jordan et al., 2014; Armijo et al., 2015). It is important to note, however, that the mentioned large-scale warping of the forearc has not been directly linked with processes operating at the interface between the oceanic Nazca plate and the continental South American plate, nor with the evolution of the Coastal Cordillera, on which this work is focused.

Following monoclinal warping and canyon incision, the landscape of the Arica region was sealed by the deposition of the Lauca-Perez ignimbrite at $2.7 \mathrm{Ma}$ (Wörner et al., 2000; Wörner et al., 2002; Garcia \& Hérail, 2005), which constitutes a relevant marker horizon for setting the base-level at that time. The occurrence of this unit at the bottom of the modern Lluta Valley indicates indeed that no net incision has affected this area since the time of deposition.

This article is protected by copyright. All rights reserved. 


\section{(B) 2.2. Structures}

The modern structures of the Western Central Andean forearc are the expression of lithospheric and crustal scale long-lived processes linked to two motion regimes: (i) the bending of the Bolivian Orocline and (ii) the subduction of the Nazca beneath the South American plate. Most of the orocline bending occurred between 40-15 Ma (Roperch et al., 2006) and might still be active nowadays (Allmendinger et al., 2005b), whereas subduction has been active since late Cretaceous time (e.g. Gregory-Wodzicki, 2000).

The result of Myr-long subduction and orocline bending is the formation of a seaward-concave margin, where plates converge perpendicularly at the hinge of the concavity and obliquely north and south of it (Fig.1). Sinistral strike-slip faulting, as is the case for the Incapuquio Fault System in the Precordillera north of $18^{\circ} \mathrm{S}$ (Jacay et al., 2002; David, 2007), accommodated counterclockwise rotation of the northern limb. Clockwise rotation was instead accommodated by dextral strike-slip faulting, as has been the case for the Atacama Fault System in the Coastal Cordillera south of $22^{\circ} \mathrm{S}$ (e.g. Brown et al., 1983; Allmendinger \& González, 2010). The segment of the forearc between ca. $18^{\circ}-22^{\circ} \mathrm{S}$ has been ascribed to the structural inner arc of the Bolivian Orocline (Gephart, 1984; Roperch et al., 2006; Allmendinger \& González, 2010) and is generally characterized by dip-slip structures. Here it is important to note that the apex of the coastline bend, where Arica is located, is $\sim 150 \mathrm{~km}$ offset north of the apex of the margin and of the orocline concavity (Fig.1). The forearc structures between $18^{\circ}-22^{\circ} \mathrm{S}$ have been shown to accommodate both $\mathrm{N}-\mathrm{S}$ and $\mathrm{E}-\mathrm{W}$ shortening: the Atajaña and Pisagua faults in the Coastal Cordillera (Allmendinger \& González, 2010) record Neogene-Quaternary N-S compression due to orocline bending. The Oxaya Anticline (Wörner et al., 2002; Zeilinger et al., 2005), together with the Ausipar and Copaquilla-Tignamar thrust systems (David, 2007) and other compressive flexures (Victor et 
al., 2004; Garcia et al., 2011) document E-W compression in the northern Chilean Precordillera due to plate convergence.

The Central Andes underwent a total shortening of 250-300 km (Oncken et al., 2006), which was accommodated mostly by fold and thrust deformation on the eastern flank of the orogen (Mcquarrie et al., 2002). In contrast, the Western Central Andean forearc accommodated no more than $3 \mathrm{~km}$ of total shortening since Oligocene time (Victor et al., 2004) and little or no shortening after $10 \mathrm{Ma}$ (Hartley et al., 2000; Schildgen et al., 2007; Thouret et al., 2007). Consistent with such a small amount of shortening, the margin-parallel compressive structures in the subaerial forearc are restricted to the Precordillera and limited in both extent and throw. Nevertheless, Armijo et al. (2015) collectively described these features as the West Andean Thrust and considered it as a relatively continuous feature along the entire Peru-Chile forearc.

A number of authors have described the kinematics of portions of the Coastal Cordillera, such as (i) the Chololo Fault System near Ilo in southern Peru (Audin et al., 2008), (ii) the Atajana and Pisagua faults between Camarones river and the city of Iquique (Allmendinger \& González, 2010) and (iii) Salar del Carmen fault at $23^{\circ} \mathrm{S}$ (Loveless et al., 2010). In these localities, faults have accommodated permanent deformation within the Coastal Cordillera throughout multiple seismic cycles, and various mechanisms such as (i) earthquake slip segmentation (Audin et al., 2008), (ii) uplift segmentation (Ortlieb, 1996; Roperch et al., 2006), (iii) lower plate thickening and (iv) upper plate extension in response to underplating (Hartley et al., 2000) have been proposed to explain their kinematics.

This article is protected by copyright. All rights reserved. 


\section{(A) 3. METHODS}

\subsection{Compilation}

We compiled published data that have been collected in the framework of various disciplines encompassing structural geology, stratigraphy, geodynamics, geomorphology, sedimentology and seismicity. In addition, we integrated data from the literature with new interpretations based on field observations, mapping on Landsat satellite imagery and geomorphic analysis performed on ASTER GDEM Digital Elevation Models. A result of this compilation is shown in Figure 4, where previously documented structures are displayed together with other yet undescribed and/or unmapped faults. This map builds the basis for the grouping of tectonic features from the same area and for linking them to the well-explored fault systems, in order to characterize the motion regimes of the different areas within the forearc. Figure 4 will also serve to visualize the spatial distribution of the various forearc structures and to compare them with the regional seismicity pattern.

\section{(B)3.2. Post-Miocene along-strike sediment supply pattern}

The forearc landscape between the Western Cordillera and the Pacific coast comprises mainly two landscape domains including: (i) the pediments (or pampas) that formed through the accumulation of sediment from laterally coalescent fans between the late Oligocene and the Miocene (Tosdal et al., 1984) and (ii) the deep canyons that have been carved since the late Miocene and host the modern perennial streams (e.g. Schildgen et al., 2007; Thouret et al., 2007; García et al., 2011). The excellent preservation of the Miocene pediplains (Székely et al., 2014) allowed us to estimate the pattern of average sediment discharge to the ocean for the past ca. 10 Myr through budgeting (e.g. Kober et al., 2006). We calculate these estimates by subtracting the Digital Elevation Model (DEM) of the current landscape, obtained from the ASTER GDEM, from a reconstructed paleo-surface representing the pampas (Garcia \& 
Hérail, 2005). This methodology infers that the pediplain has constituted a gently dipping topographic ramp prior to dissection (Kober et al., 2006), which started around $10 \mathrm{Ma}$ and became regionally relevant between 9 and 6 Ma (Hoke et al., 2007; Schildgen et al., 2007; Thouret et al., 2007; Schildgen et al., 2009; Jordan et al., 2014). This latter surface was reconstructed within a Geographic Information System environment where each cell was assigned the maximal elevation value encountered within a 7.5-km-diameter circular window. Note that the width of the moving window was selected in order to allow the interpolation of the surface even across the broadest canyons. We then clipped the obtained volume to 4 macro-catchments, referred here to the Tambo, Ilo, Arica Bend, and Tana sectors (Table 1). Each macro-catchment represents a cluster of all the catchments that have supplied their sediments to the same along-strike segment, according to the configuration of the submarine valleys (Fig.1). We infer that all material that would backfill the current canyons of the forearc has been supplied to the ocean throughout the past ca. $10 \mathrm{Myr}$, and that this supply of sediment occurred at the same time north of the bend, at the Arica Bend itself and south of it. We additionally acknowledge that the interpolation method might yield an overestimation of the eroded volumes. However, because the uncertainties do not vary along-strike, the interpretation, which mainly relies on the relative pattern of inferred sediment flux, will not substantially be biased by this approach. In order to estimate a relative uncertainty on these values, we also re-iterated the surface interpolation and changed the radius of the sampling window accordingly (Table 1). We then calculated the standard deviation of all estimates in order to assess the sensitivity of the resulting pattern with respect to the sampling window size.

This article is protected by copyright. All rights reserved. 


\section{RESULTS}

\section{(A) 4.1. Structures}

We compiled published and new structural data into a large-scale structural map (Fig.4), which shows the spatial orientation of the different deformation styles that have been affecting the Western Andean forearc between $17^{\circ}-21^{\circ} \mathrm{S}$. The coastal area of southern Peru presents several NE-SW oriented faults (Fig.4a). These features are up to $50 \mathrm{~km}$ long and restricted to the Coastal Cordillera, where they are homogeneously distributed. We relate them to the motion regime of the Chololo Fault System (Audin et al., 2008) because of similar extent, orientation and spatial distribution. This structure is a composite normalsinistral fault system that accommodated segmentation of uplift along the Coastal Cordillera since Oligocene time (Roperch et al., 2006) and trench-parallel extension of the upper crust in response to segmented slip at interplate depth since at least Quaternary time (Audin et al., 2008).

South of Arica, a nearly $90 \mathrm{~km}$-long segment of the Coastal Cordillera has been cut by a suite of NW-SE and NE-SW trending faults (Fig.4f). Although these features show crosscutting relationships, details regarding the relative chronologies and the slip directions cannot be precisely constrained because of multiple reactivations, causing a pattern that is difficult to decipher and has not been investigated so far.

South of the Camarones valley (Fig.4h) several N-S and E-W trending faults cut the topography of the Coastal Cordillera. The N-S trending faults show similar orientation and extent to previously documented features south of $22^{\circ} \mathrm{S}$ (Allmendinger \& González, 2010), where they are described as normal faults that have accommodated upper plate extension. Nevertheless, cases of reversed normal faults show that these structures may change their 
kinematics depending on the period of the seismic cycle (Loveless et al., 2010). The E-W trending features are instead considered as reverse faults that have accommodated orocline bending (Allmendinger et al., 2005a) as mentioned above.

The flat topography of the 50-km-long coastal stretch immediately north of Arica (Fig.4d) shows no surface expressions of deformation, unlike the other mentioned coastal areas north and south of it.

The topography of the Precordillera in southern Peru shows several NW-SE oriented lineaments that parallel the strike of the orogeny (Fig.4b). Among all these features, the Incapuquio Fault System (Jacay et al., 2002; David, 2007) has been described as an active left-lateral lithospheric-scale structure that has accommodated anti-clockwise rotation of the southern Peruvian forearc due to orocline bending since Oligocene times (Roperch et al., 2006). We therefore consider all the analogous mapped faults to follow the same large-scale kinematics.

The easternmost portion of the Central Depression inland from Arica is cut by the structures of the Oxaya Anticline (Wörner et al., 2002), and by the Ausipar and CopaquillaTignamar thrust systems (David, 2007) (Fig.4d). These structures, which where active before $\sim 10 \mathrm{Ma}$, accommodated a small amount of forearc shortening and steepening (Hartley et al., 2000; Wörner et al., 2002; Zeilinger et al., 2005). In a similar structural position, but farther northwest (Fig.4c) and south (Fig.4g/i), the eastern border of the Central Depression is now uplifted to elevations higher than the Coastal Cordillera and cut by several trench-parallel blind faults. We consider these features as analogous to the compressive flexures that have accommodated small amounts of shortening throughout the Miocene (Garcia et al., 2011) and that are possibly still active (Hall et al., 2012), which is also consistent with the recent higher-than-average seismic activity in the area (Fig.4g/i)

This article is protected by copyright. All rights reserved. 
At a smaller scale, between the Azapa and Tana Rivers, new mapping on orthophotos reveals that low-order NW-oriented intermittent channels are sharply deviated by $90^{\circ}$ within a few meters, or abruptly terminate, where they have been captured by NW-SE-oriented structures (Fig.5b/d). This pattern points to a tectonic control where the drainage network of low-order channels has been preferentially oriented and reorganized along minor faults. Moreover, the propagation of debris-flow fans terminates where the slope has been locally inverted in response to compressive flexuring (Fig.5c). These commonly bivergent faults have most likely been formed through a combination of interseismic and coseismic permanent deformation, which are considered to accommodate the slip deficit (Loveless et al., 2009; Allmendinger \& González, 2010; Aron et al., 2013).

\section{(B) 4.2 (Post-Miocene) along-strike pattern of sediment supply}

Our estimates of post-Miocene cumulative eroded volumes range roughly between 1000 and $9000 \mathrm{~km}^{3}$ (Table 1, Fig.6). The lowest value has been calculated for the Tana catchment, whose canyon is only half as deep as the Camarones valley (Fig.2a). In contrast to this picture, our estimates yield the highest value of sediment discharge at the Arica Bend, where the Coastal Cordillera is absent (Fig.6). After changing the sampling window of the surface interpolation as a sensitivity test, we found that the calculated volumes do not change significantly for diameter sizes between 5 and $10 \mathrm{~km}$ (Table 1). Indeed, although the standard deviation of the values can be up to $25 \%$, depending on the chosen size of the sampling window, the ranking between the macro-catchments does not change.

Results thus show that, from late Miocene onward, the largest volumes of sediment have been delivered to the Pacific Ocean at the Arica Bend, where the Coastal Cordillera is absent and no surface expression of past and/or current crustal deformation is present. 


\section{(A) 6. INTERPRETATION}

\subsection{Pattern of deformation in the forearc}

As shown in Figure 4, none of the deformation styles presented above seems to have perturbed the $50 \mathrm{~km}$-wide flat coastal area north of Arica (Fig.4d). This observation is consistent with the occurrence of the 2.7 Ma-old Lauca-Perez Ignimbrite at the bottom of the Lluta Valley $\sim 13 \mathrm{~km}$ from the coast (Wörner et al., 2002; Garcia \& Herail, 2005). The high erodibility of this unit suggests indeed that, if the area had experienced tectonic perturbations since the time of deposition, the ignimbrite would have been removed through channel incision in case of relevant uplift, or alternatively buried by fluvial deposits in case of significant subsidence and related sedimentation. We thus consider that this particular transect has experienced neither deformation, nor uplift of regional relevance throughout the Quaternary, possibly stretching back to the Miocene, as already hypothesized by Kober et al. (2006).

As also shown in Figure 4, the portion of forearc between the coast of the Arica Bend and the trench is subject to exceptionally low seismicity, which seems to imply a lack of crustal deformation in the same forearc sector. This is consistent with the documented pattern of late Quaternary uplift (Regard et al., 2010; Melnick, 2016), which has involved the regions north and south of Arica, but not the coast at the bend itself.

\section{(B) 6.2. Sediment supply to the ocean prior to forearc incision $(\sim 10 \mathrm{Ma})$}

South of the Arica Bend, stratigraphic relationships indicate that the Coastal Cordillera operated as a sedimentary barrier (Fig.3c), retaining the late Oligocene-Miocene coarse-grained clastic and volcanoclastic material (Azapa, Oxaya and El Diablo Formations of northern Chile) derived from the Western Cordillera in the Central Depression. 
Volcanoclastic deposition in the Central Depression built up the pediplains that link the Precordillera with the Coastal Cordillera.

North of the Arica Bend, a large portion of the coarse-grained Oligo-Miocene material sourced in the Western Cordillera appears to have been trapped east of the Coastal Cordillera, while only a small portion mixed and/or interfingered with the deposits on its western flank. We base this interpretation on the occurrence of the coarse-grained fluviovolcanoclastic suite comprising the upper Moquegua and Huaylillas Formations east of the Central Depression, while time equivalent deltaic and marine sediments are found in the Camana formation west of the Coastal Cordillera (Fig.3a) (Roperch et al., 2006; Thouret et al., 2007; Alván \& von Eynatten, 2014). Provenance studies performed by Alván et al. (2015) indeed suggest that the Camana formation was predominantly sourced from the Coastal Cordillera itself throughout its depositional time. An exception is represented by the uppermost late Miocene-Pliocene Camana B unit, which appears to share the source with the continental Moquegua D formation, where the material was derived from the Western Cordillera.

In contrast to what we observe north and south of the bend, Kober et al. (2006) suggested that the coastal segment of the Arica Bend has operated as an open drainage system at least since the beginning of the Miocene. These authors related this to the absence of a sedimentary barrier (Fig.3b). We therefore infer that during the Miocene, larger volumes of sediments were supplied from the Arica Bend to the ocean compared to the adjacent coastal regions north and south of it.

\section{(B) 6.3. Sediment supply to the ocean during forearc incision}

The sediment supply data obtained through our estimates of post-10 Ma eroded volumes imply that the sediment discharge to the Pacific Ocean has been markedly different 
at the Arica Bend compared to the adjacent regions. This pattern is linked to the concave shape of the forearc, which conveys six major channels (Sama, Caplina, Lluta, Azapa, Vitor and Camarones) and their loads towards the Arica Bend (Fig.1). Here, the total supplied volume is approximately twice as large as the second highest value (Tambo catchment, southern Peru) and 9 times larger than what has been inferred for the Tana catchment (northern Chile) (Table 1, Fig.6). The low value obtained for the Tana catchment is consistent with the remarkably shallower incision of its main channel (Tana river) in the Central Depression, which also seems to confirm the validity of our approach. Moreover, KirkLawlor et al. (2013) have shown that the Tana river system has been able to breach through the Coastal Cordillera only after 3.5 Ma. Between the Tana canyon and the mouth of the Loa river (Fig.1), the Coastal Cordillera of northern Chile reaches its highest elevation, and the neighboring Central Depression has accumulated sediments also during the time when the other segments of the Western Central Andean forearc were affected by incision (Jordan et al., 2014; Armijo et al., 2015).

\section{(B) 6.4. Sediment path between the coast and the trench}

We have shown that sediment supply to the ocean has been higher at the Arica Bend than in the adjacent regions north and south of it. This seems to have occurred both during late Oligocene-late Miocene times and after late Miocene times respectively, as outlined above. In order to assess whether this pattern has persisted also in the submarine realm down to the trench, we need to discuss (i) possible offshore sinks other than the trench itself, and (ii) the dynamics of submarine sediment transport.

The submarine realm of the Western Central Andean wedge is characterized by a string of three forearc basins bordering the coast at depths between 400-1600 m b.s.1.. From north to south, these basins are: (i) the Arequipa Basin of southernmost Peru, (ii) the Arica 
Basin at the bend and (iii) the Iquique Basin offshore northernmost Chile (González, 1989; Armijo et al., 2015). Based on seismic surveys within the area, Coulbourn \& Moberly (1977) and González (1989) showed that these wedge-top basins are bound by the continental scarp and by structural highs, which locally invert the west-dipping slope, thereby forming accommodation space. According to the same authors, the thickest sediment fill of the PeruChile submarine forearc is found in the Arica Basin, where the sedimentary pile has been estimated to reach thicknesses between 1500 to $4000 \mathrm{~m}$ (Coulbourn \& Moberly, 1977; González, 1989). The age of these offshore deposits is unknown, but the presence of a sedimentary pile with large thicknesses seems to corroborate our findings that sediment supply to the Pacific Ocean at the Arica Bend has been larger during most of the time.

Although the along-strike continuity of these three basins is poorly constrained, 2D reconstructions provided by Coulbourn \& Moberly (1977) imply that the centers of both the Arequipa and Iquique Basins are characterized by topographic lows, denoting an underfilled stage, while the deposits in the Arica Basin overlap the seaward structural high, which indicates an overfilled stage. Based on these observations, we infer that the postulated pattern of along-strike sediment supply might have not been altered by the mentioned offshore forearc basins. We emphasize, however, that because the age of these forearc basins remains unknown, we cannot constrain the chronological framework of this observation nor can we confirm the rates at which this material has been supplied.

Von Huene et al. (1999) observed that in northern Chile submarine sedimentation does not occur exclusively in the aforementioned basins. Accordingly, the material deposited between and beyond the basins would constitute an unstable surficial blanket that contributes to the occurrence of mass-wasting processes, such as turbidity currents and slumping. In this regard, the present bathymetry of the Arica Bend constrains the path of the submarine sediment transport processes (Fig.1). As nearly all major submarine channels between Sama 
and Camarones (Fig.1) converge towards the same trench segment (offshore Arica), the large majority of the material mobilized through submarine mass-wasting processes, or supplied from the onshore streams in this region, would have eventually contributed to trench sedimentation offshore of Arica. In summary, whether the sediments have been directly deposited in the trench after overfilling the offshore basin, or supplied through mass-wasting, the trench of the Arica Bend may have received significantly larger volumes of sediment relative to the adjacent segments to the north and to the south.

\section{(A) 7. DISCUSSION}

\section{(B) 7.1. Potential conditions affecting long-term coupling and coastal uplift}

The presented stratigraphic and structural data show that subduction processes have not resulted in the uplift of the Coastal Cordillera in the Arica area since at least Miocene times, while the regions north and south of it show evidence of long-lived upper crustal deformation, resulting in the still active uplift of the Coastal Cordillera. As introduced above, we interpret this Myr-long coastal uplift pattern as the topographic expression of the degree of long-term coupling at work along the margin. In particular, the differences in uplift and seismicity (Fig.6) require a mechanism where the friction between the Nazca and South American plates is larger north and south of the Arica Bend than at the bend itself (Chlieh et al., 2011; Béjar-Pizarro et al., 2013; Li et al., 2015). The presence of a low-friction anomaly at the Arica Bend is also consistent with the historically low seismic activity of this margin segment (Fig.4, 6), which has been related to a lower accumulation of stress in the corresponding segment of the plate-boundary (Chlieh et al., 2011; Béjar-Pizarro et al., 2013; Métois et al., 2016). Additional support for this interpretation is offered by the concepts of critical taper wedge models (Davis et al., 1983; Dahlen et al., 1984). These models predict that a supercritical wedge, as inferred for the western side of the Andes by Norton \& 
Schlunegger (2011), is expected to deform either through stable sliding or tilting, excluding internal thickening through thrusting and/or plastic deformation. In such a state, the taper angle depends on the shear stresses at the plate interface, the dip angle of the décollement horizon and the mechanical strength of the rocks within the wedge. While the dip angle of the Nazca plate does not vary between Ilo and Iquique (Cahill \& Isacks, 1992; Maksymowycz, 2015), the offshore topographic slope is $>1^{\circ}$ steeper in northern Chile and $0.5^{\circ}$ steeper in southern Peru than at the Arica Bend (Fig.2; Maksymowicz, 2015). This implies that the basal friction needed to sustain the supercritical wedge is lower at the Arica Bend than north and south of it. In the following paragraphs we examine which processes might have induced such an anomaly of interplate friction and coastal uplift.

\section{(C) 7.1. Subducting topography}

Topographic features entering the trench are considered to strongly influence the pattern of friction at the plate interface and the rate of subduction erosion (Kukowski \& Oncken, 2006; Contreras-Reyes \& Carrizo, 2011). At the latitude of the Arica Bend, the Nazca plate hosts the Iquique Ridge (Fig.1, 6), which is a broad region with a shallow seafloor and several seamounts. The subduction of this buoyant swell is considered to have increased the friction at the plate interface along its entire extent (Contreras-Reyes \& Carrizo, 2011) and more generally, subduction of such topographic features are commonly noted to drive increased uplift at the margin (e.g. Wipf et al., 2008). Therefore, while the subduction of the buoyant Iquique Ridge might explain the high seismic coupling and large subduction erosion generally observed along the northernmost Chilean margin (Kukowski \& Oncken, 2006), it cannot be considered as a potential driver for the low long-term coupling that we infer at the plate interface of the Arica Bend. This would indeed require the presence of a topographic feature able to reduce the friction at the plate interface over a limited reach, 
which has not been observed. Besides, a very high seismic coupling is also inferred for the segment north of the Arica Bend, offshore of Ilo (e.g. Li et al., 2015), where no seamounts are being subducted. Finally, subduction of topographic features are thought to exert only a transient effect on seismic coupling (Maksymowicz, 2015), whereas we infer a Myr-long low-coupling anomaly.

\section{(C) 7.1.2. Subduction obliquity}

The angle of subduction relative to the margin's strike affects plate-convergence rates (Jordan et al., 2001) and the kinematics of deformation within the forearc, as shown by Audin et al. (2008) and highlighted by the results of our compilation (Fig.4). The obliquity of convergence, here referred to as the angle of divergence from the margin-perpendicular, varies along the Peru-Chile trench (Fig.6). Convergence occurs orthogonally between $20.1^{\circ}$ $20.5^{\circ} \mathrm{S}$, offshore the city of Iquique, it reaches $\sim 20^{\circ}$ of obliquity at $22^{\circ} \mathrm{S}$ in northern Chile, where the Coastal Cordillera reaches altitudes higher than $1400 \mathrm{~m}$ a.s.l., and the maximum obliquity of $\sim 39^{\circ}$ occurs in southern Peru $\left(17^{\circ}-18^{\circ} \mathrm{S}\right)$, where elevations of the coastal range exceed $1000 \mathrm{~m}$ a.s.l.. Offshore the area of low uplift and seismicity at the Arica Bend, obliquity is $\sim 23^{\circ}$ (Fig.6). Consequently, the poor correlation between the patterns of subduction obliquity and inferred long-term coupling, seems to favor other possible drivers for the uplift anomaly along the Arica Bend.

\section{(C) 7.1.3. Subduction curvature}

Another driving force for the uplift anomaly near Arica might be the seaward concave curvature of the margin. In this context, results of numerical models about the evolution of concave forearc systems have shown that the curvature hinge yields a stress regime that differs from that of the neighboring limbs (Bonnardot et al., 2008; Boutelier \& Oncken, 
2010). While Bonnardot et al. (2008) predicted the occurrence of extension in the hinge of a seaward concave forearc, Boutelier \& Oncken (2010) postulated trench-parallel compression in the same position. The model by Bonnardot et al. (2008) shows that subducted material at the hinge of a concave margin tends to escape from the curvature apex towards the limbs, therefore inducing trench-parallel extension and subsidence. The authors associate the predicted extensional regime with the Oligo-Miocene extension and magmatism event observed by Jordan et al. (2001) in the Western Central Andean forearc. In contrast, the model by Boutelier \& Oncken (2010) shows that shear traction may induce trench-parallel compression at the hinge of a concave margin. The authors relate this postulated compressional regime to the presence of a thickened crust in the curvature center (the Altiplano). Although both models provide interesting insights on the possible tectonic evolution of the Altiplano and the Bolivian Orocline, their results are difficult to relate to the Coastal Cordillera and particularly to the Arica Bend features, because our obervations do not correspond with those inferred from the models. In particular, both models predict stress patterns within a scale at least one magnitude larger than observed there, both in space and time. Morover, as already pointed out above, the symmetry of the oceanward concavity is ca. $150 \mathrm{~km}$ offset towards the south of the Arica Bend (Fig.1, 6), which suggests that the current stress pattern induced by the margin curvature may not be linked to today's morphology of the Arica Bend. Because we observe relative subsidence at the Arica Bend, however, we would favor the Bonnardot et al. (2008) model, although the structures that should accommodate the predicted extensional regime have not been observed yet at the surface, and no geophysical data is available to assess their occurrence below the sediments at the Arica Bend.

This article is protected by copyright. All rights reserved. 
In light of these observations, we anticipate that the oceanward concavity of the margin may have exerted a significant role in initiating the tectono-geomorphic evolution of the Arica Bend, but we expect an alternative mechanism to dominate the most recent history of this feature. We justify this approach because the margin concavity of the central Andes has been migrating and changing its radius through time as a function of the shifts in convergence rate and obliquity (McQuarrie, 2002), until it eventually reached its present setting at roughly 15 Ma (Jordan et al., 2001; McQuarrie, 2002; Roperch et al., 2006). Therefore the subduction curvature constitutes a variable, rather than a constant in the longterm shaping of the Arica Bend.

\section{(C) 7.1.4. Thickness of the subduction channel}

Subduction channels have been described as the shear zones established between subducting and overriding plates, where they comprise a stack of polygenic sedimentary rocks with low mechanical strengths (England \& Holland, 1979; Shreve \& Cloos, 1986; Mancktelow, 1995). The thickness of the subduction channel strongly depends on sedimentation within the trench. Therefore, it is expected to be thin where sediment supply rates are low and thicker where the corresponding flux is larger. Moreover, this feature appears to have significant control on the frictional properties of the plate interface and the related seismic ruptures, as outlined by Ruff (1989) and Contreras-Reyes \& Carrizo (2011). According to these authors, a portion of a margin characterized by a relatively thick subduction channel is likely to be less locked than adjacent segments where corresponding thicknesses are low. The subduction of unconsolidated trench sediments should increase the pore-fluid pressure, inducing in turn a decrease in interplate friction (Dahlen et al., 1984). We have argued that the trench offshore the Arica Bend has received higher sediment supply than the adjacent segments north and south of it for the past ca. $10 \mathrm{Ma}$ and most likely throughout 
the entire Miocene. We therefore consider this long-lasting trench sedimentation pattern as a good candidate to explain the observed long-term low coupling as discussed in the next section.

We acknowledge that estimates of the current Peru-Chile trench fill published by Schweller et al. (1981) show a pattern of trench sedimentation that contrasts with our inferences, where sediment fill is most abundant offshore the Ocoña and Camana rivers in southern Peru $\left(16.5-17^{\circ} \mathrm{S}\right)$, decreases towards the Arica Bend and becomes negligible in northern Chile (Fig.6). Nevertheless, the trench segment offshore the Ocoña River is also the location where the Nazca Fault Zone is in subduction (Fig.6; Contreras-Reyes \& Carrizo, 2011). Accordingly, Robinson et al. (2006) interpreted the high seismic coupling of this segment as a direct consequence of the subduction of this highly irregular topographic feature. The same authors additionally used the rupture propagation of the $2001 \mathrm{M} 8.4$ Arequipa earthquake to confirm their initial interpretation.

Note also that data about the current trench fill cannot be used to exclude the occurrence of high trench sedimentation during the Mio-Pliocene time. In this context, it must be considered that as result of $>20$ Myr-long subduction processes, all sediments deposited during Mio-Pliocene times might already have been dragged into the plate interface, and that the current trench fill may represent the material that has been deposited throughout the Quaternary only. Schweller et al. (1981), indeed, proposed that under the current convergence rate of $\sim 10 \mathrm{~cm} / \mathrm{y}$, the modern abundant trench fill south of $33^{\circ} \mathrm{S}$ in southern Chile might be younger than 1 Ma. At the Arica Bend, the minimum plateconvergence rate throughout Mio-Pliocene time has been $7 \mathrm{~cm} / \mathrm{y}$ (Jordan et al., 2001), which integrated over $20 \mathrm{Myr}$, yields a total of $1400 \mathrm{~km}$ northeastward motion of the Nazca plate 
relative to the South American plate. This motion has been partly compensated by a maximum of $300 \mathrm{~km}$ of total Andean shortening (Oncken et al., 2006) and a maximum of 60 $\mathrm{km}$ eastward margin retreat due to subduction erosion during the same time-span (Kukowski $\&$ Oncken, 2006). The remaining $\sim 1000 \mathrm{~km}$ of Mio-Pliocene plate convergence must have been accommodated by subduction of the Nazca plate below South America. With these calculations, we emphasize that the current trench-fill data might not be appropriate to extrapolate paleo-sedimentation patterns older than Quaternary time in the Peru-Chile setting. The general lack of data about the residence time of trench sediments, however, hinders any further constraints on these inferences.

\section{(B) 7.2. The evolution of the Arica Bend}

Von Huene \& Ranero (2003) have analyzed the modes of subduction erosion offshore the city of Antofagasta $\left(23.4^{\circ} \mathrm{S}\right)$, inferring that the frictional behavior of the sedimentstarved northern Chilean margin may be analogous to that of a sediment-accreting one. Consequently they concluded that the plate interface of the Western Central Andean subduction zone may not at all be locked. However, GPS-derived measures of surface displacement in the forearc (e.g. Kendrick et al., 2001) and the derived estimates of seismic coupling elaborated in independent studies (Chlieh et al., 2011; Béjar-Pizarro et al., 2013, Li et al., 2015; Métois et al., 2016), show that the seismic cycle is dominated by a stick-slip behavior, which is consistent with a locked plate interface. Accordingly, we tentatively decide not to follow the final conclusions of von Huene \& Ranero (2003).

From another perspective, Lamb \& Davis (2003) proposed that low sediment fluxes to the trench, as a consequence of the onset of aridity in the forearc, induced the Cenozoic uplift of the Central Andes at a large scale. Although alternative reconstructions of forearc 
deformation, sedimentation and paleoclimate in the Western Central Andes have been proposed (Hartley, 2005), Lamb \& Davis's idea (2003) that trench sedimentation might strongly affect seismic coupling remains valid (e.g. Contreras-Reyes \& Carrizo, 2011).

Here, we propose that if trench sedimentation influences seismic coupling, then it must affect the deformation pattern of the Coastal Cordillera, which sits on the landward termination of the currently locked zone. Accordingly, we interpret the Coastal Cordillera to represent a trench-parallel upper-crustal wave front that expresses the degree to which the plate interface has been locked. This wave would then show a larger amplitude (higher mean elevation, Fig.6) where the coupling is stronger, possibly in response to sediment starvation in the trench (Fig.7a; Lamb \& Davis, 2003), while the opposite would be inferred where the subduction channel has been thickened and lubricated by a larger sediment supply (i.e., the Arica Bend, Fig.7b). However, it remains unclear whether a larger sediment supply, in a relative sense, would be the cause of the low long-term coupling between the subducting and overriding plates, or the response of the low coastal uplift, which would favor the sediments reaching the ocean as discussed above. Therefore, we favor a scenario where the growing seaward concavity of the margin might have served as the initiator of what could be considered as a "chicken and egg" problem. In the following sections we propose a three-step temporal and mechanical model for the evolution of the Arica Bend.

\section{(C) 7.2.1. Before 25 Ma: Orocline bending and differential uplift of the Coastal Cordillera}

Following the model elaborated by Bonnardot et al. (2008), the early Oligocene formation of the Bolivian Orocline could have been accompanied by a distinct partitioning of the stresses within the forearc curvature. Accordingly, in the overriding plate, the point of maximum concavity would have been characterized by extension and subsidence, while the curvature limbs to the north and south of the bend would have experienced trench-parallel 
compression and uplift (Fig.8a). In this model, the stress-pattern induced by the growing curvature would have led to the formation of a funnel-shaped forearc (which we still observe today), in which the flux of erosional products generated by the growth of the Andean orogeny would be concentrated into the subsiding Arica Bend.

\section{(C) 7.2.2. 25-10 Ma: Volcanoclastic sedimentation pattern in a growing curvature}

Once the along-strike erosional pattern had been established, a positive feedback mechanism could have initiated. The uplifting Coastal Cordillera would dam the Central Depression basin and condition the formation of endorheic drainage in northern Chile and mostly endorheic in southern Peru (Fig.3, 7a, 8b). As a consequence, low trench sedimentation would have contributed to enhance the friction at the plate interface, with the result that the compressional shortening and uplift of the Coastal Cordillera would have increased. At the same time, volcanoclastic deposition would have further contributed to the subsidence of the Central Depression through sedimentary loading (Fig. 7a). A contrasting positive feedback would have likely been established where the subsiding coast of the Arica Bend was not closing the drainage system (Fig.7b, 8b), and where long-lasting sediment discharge to the trench could have maintained the interplate friction at relatively-low levels, thereby decelerating, or inhibiting lower-crust shortening and coastal uplift.

The continental volcanoclastic stratigraphy of the Peru-Chile forearc (Fig.3) implies that these mechanisms have likely been at work from the Oligocene-Miocene boundary until $\sim 10 \mathrm{Ma}$, although absolute estimates of the Oligo-Miocene sediment supply to the trench cannot be well constrained. Therefore, considering that the concavity of the margin kept accentuating until 15 Ma (Jordan et al., 2001; McQuarrie, 2002; Roperch et al., 2006), we tentatively invoke a scenario where the evolution of the Arica Bend and the Coastal Cordillera was most likely dominated by the tectonically driven pattern of stresses in the 
forearc throughout this time span. However, we do also consider that endorheic drainage south of the Arica Bend, paired with partially closed drainage north of it and an open drainage at the bend itself (Fig.8b) would have offered favorable conditions for amplifying the initiated deformational pattern.

\section{(C) 7.2.3. After 10 Ma: Canyon incision, feedback mechanisms take over}

At ca. 10 Ma the curvature of the western Andean margin was established, most of the continental sedimentation ceased and the forearc experienced a period of monoclinal warping and incision (e.g. Schildgen et al., 2007). Most of this incision occurred roughly between 10 Ma and the Quaternary, when the trench offshore Arica received a larger volume of sediment than to the north and south, due to the funnel-shape of the forearc (Table 1; Fig.6, 8c). We consider it likely that this along-strike sediment discharge pattern was able to maintain, and possibly amplify, the feedback mechanisms initiated in Late Oligocene times. As already discussed above, the area that lacks surface expressions of crustal deformation (the coast of the Arica Bend) is offset from the current point of orthogonal subduction and curvature apex of the margin (e.g. Fig.1, 6). This symmetry offset suggests that in recent times (i.e. Late Neogene-Quaternary) the stress pattern induced by the margin concavity did not affect the uplift pattern of the Coastal Cordillera, which might ultimately be the expression of the positive feedback mechanisms outlined above.

Studies on modern trench-fill (Schweller et al., 1981; Fig.6) show that the discussed pattern of sediment supply to the trench must have changed sometimes during the Quaternary. However, a time-lag between trench sedimentation, coastal uplift and deformation must be taken into account and still needs to be constrained.

This article is protected by copyright. All rights reserved. 


\section{(A) 8. CONCLUSIONS}

The search for controls on the uplift anomaly in the area surrounding the Arica Bend has been a long-standing problem, which, however, has received little attention during the past years. This paper resumes current interpretations and provides a possible solution. In particular, we favor a mechanism where the formation of the seaward concavity of the Bolivian Orocline seems to have caused forearc extension at the point of maximum curvature. The resulting low uplift rate at the coastline bend would have initiated a feedback mechanism, where the interplay between high sediment supply, low long-term coupling, low seismicity and low coastal uplift has maintained a situation where the Coastal Cordillera at the Arica Bend has been absent during geological times, which contrasts to the long-lasting uplift north and south of it.

Our interpretations rely on a compilation of geological data, on estimates of sediment supply, and on mapping. Further investigations in the offshore forearc would therefore provide better constraints on the residence time of sediments in the trench and the submarine pattern of sediment transport in this poorly studied segment of the Western Central Andes.

\section{ACKNOWLEDGMENTS}

We are very grateful to Taylor Schildgen and Gerhard Wörner, whose reviews greatly helped improving the final manuscript. We do also thank Armin Dielfolder for his interest and fruitful discussions as well as Naki Akçar for his support during fieldwork. Research was financed through a grant of the Swiss National Science Foundation (project No. 200020121680) awarded to Schlunegger. The ASTER GDEM data are a product of METI and NASA, and are distributed by the Land Processes Distributed Active Archive Center (LP DAAC), located at USGS/EROS, Sioux Falls, SD (http://lpdaac.usgs.gov). The Landsat and 
the ANSS Comprehensive Catalog data are available thanks to the U.S. Geological Survey.

\section{CONFLICT OF INTEREST}

No conflict of interest declared.

\section{REFERENCES}

ALLMENDINGER, R.W., GONZÁLEZ, G., YU, J., HOKE, G. \& ISACKS, B. (2005a) Trench-Parallel Shortening in the Northern Chilean Forearc: Tectonic and Climatic Implications. Geological Society of America Bulletin, 117, 89-104.

ALLMENDINGER, R.W., SMALLEY, R., BEVIS, M., CAPRIO, H. \& BROOKS, B. (2005b) Bending the Bolivian Orocline in Real Time. Geology, 33, 905-908.

ALLMENDINGER, R.W. \& GONZÁLEZ, G. (2010) Invited Review Paper: Neogene to Quaternary Tectonics of the Coastal Cordillera, Northern Chile. Tectonophysics, 495, 93-110.

ALVÁN, A. \& VON EYNATTEN, H. (2014) Sedimentary Facies and Stratigraphic Architecture in CoarseGrained Deltas: Anatomy of the Cenozoic Camaná Formation, Southern Peru $\left(16^{\circ} 25^{\prime} \mathrm{S}\right.$ to $17^{\circ}$ $15^{\prime}$ S). Journal of South American Earth Sciences, 54, 82-108.

ALVÁN, A., VON EYNATTEN, H., DUNKL, I. \& GERDES, A. (2015) Zircon U-Pb geochronology and heavy mineral composition of the Camaná Formation, southern Peru: Constraints on sediment provenance and uplift of the Coastal and Western Cordilleras. Journal of South American Earth Sciences, 61, 14-32.

ANSS Comprehensive Catalog (http://earthquake.usgs.gov/earthquakes/search/)

ARMIJO, R. \& THIELE, R. (1990) Active faulting in northern Chile: ramp stacking and lateral decoupling along a subduction plate boundary?. Earth and Planetary Science Letters, 98, 4061.

ARMIJO, R., LACASSIN, R., COUDURIER-CURVEUR, A. \& CARRIZO, D. (2015) Coupled tectonic evolution of Andean orogeny and global climate. Earth-Science Reviews, 143, 1-35.

ARON, F., AlLMENDINGER, R. W., CEMBRANO, J., GONZÁLEZ, G. \& YAÑEZ, G. (2013) Permanent Fore-Arc Extension and Seismic Segmentation: Insights from the 2010 Maule Earthquake, Chile. Journal of Geophysical Research: Solid Earth, 118, 724-739.

AUDIN, L., LACAN, P., TAVERA, H. \& BONDOUX, F. (2008) Upper Plate Deformation and Seismic Barrier in Front of Nazca Subduction Zone: The Chololo Fault System and Active Tectonics Along the Coastal Cordillera, Southern Peru. Tectonophysics, 459, 174-185.

BARNES, J. B., EHLERS, T. A., INSEL, N., MCQUARRIE, N. \& POULSEN, C. J. (2012) Linking orography, climate, and exhumation across the central Andes. Geology, 40, 1135-1138.

BÉJAR-PIZARRO, M., SOCQUET, A., ARMIJO, R., CARRIZO, D., GENRICH, J. \& SIMONS, M. (2013) Andean Structural Control on Interseismic Coupling in the North Chile Subduction Zone. Nature Geoscience, 6, 462-467.

BINNIE, A., DUNAI, T. J., BINNIE, S. A., VICTOR, P., GONZÁLEZ, G. \& BOLTEN, A. (2016) Accelerated late quaternary uplift revealed by $10 \mathrm{Be}$ exposure dating of marine terraces, Mejillones Peninsula, northern Chile. Quaternary Geochronology, in press.

BONNARDOT, M.-A., HASSANI, R., TRIC, E., RUELLAN, E. \& RÉGNIER, M. (2008) Effect of Margin Curvature on Plate Deformation in a 3-D Numerical Model of Subduction Zones. Geophysical Journal International, 173, 1084-1094.

BOUTELIER, D. A. \& O. ONCKEN (2010) Role of the plate margin curvature in the plateau buildup: Consequences for the central Andes. Journal of Geophysical Researc: Solid Earth (19782012), 115.

CAHILL, T. \& ISACKS, B.L. (1992) Seismicity and Shape of the Subducted Nazca Plate. Journal of

This article is protected by copyright. All rights reserved. 
Geophysical Research: Solid Earth (1978-2012), 97, 17503-17529.

CHARRIER, R., HÉRAIL, G., PINTO LINCONIR, L.D.C., RIQUELME, R., FARÍAS, M. \& , MUÑOZ N. (2013) Cenozoic Tectonic Evolution in the Central Andes in Northern Chile and West Central Bolivia: Implications for Paleogeographic, Magmatic and Mountain Building Evolution. International Journal of Earth Sciences, 102, 235-264.

CHLIEH, M., PERFETTINI, H., TAVERA, H., AVOUAC, J.P., REMY, D., NOCQUET, J.M., ROLANDONE, F., BONDOUX, F., GABALDA, G. \& BONVALOT, S. (2011) Interseismic Coupling and Seismic Potential Along the Central Andes Subduction Zone. Journal of Geophysical Research: Solid Earth (1978-2012), 116.

CLIFT, P. \& VANNUCCHI P. (2004) Controls on tectonic accretion versus erosion in subduction zones: Implications for the origin and recycling of the continental crust. Reviews of Geophysics, 42.

COIRA, B., DAVIDSON, J., MPODOZIS, C. \& RAMOS, V. (1982) Tectonic and magmatic evolution of the Andes of northern Argentina and Chile. Earth-Science Reviews, 18, 303-332.

COMTE, D. \& PARDO, M. (1991) Reappraisal of Great Historical Earthquakes in the Northern Chile and Southern Peru Seismic Gaps. Natural Hazards, 4, 23-44.

CONTRERAS-REYES, E. \& CARRIZO, D. (2011) Control of high oceanic features and subduction channel on earthquake ruptures along the Chile-Peru subduction zone. Physics of the Earth and Planetary Interiors, 186, 49-58.

COULBOURN, W. T. \& MOBERLY, R. (1977) Structural evidence of the evolution of fore-arc basins off South America. Canadian journal of earth sciences, 14, 102-116.

DAHLEN, F., SUPPE, J. \& DAVIS, D. (1984) Mechanics of Fold-and-Thrust Belts and Accretionary Wedges: Cohesive Coulomb Theory. Journal of Geophysical Research: Solid Earth (19782012), 89, 10087-10101.

DAVID, C. (2007) Comportement Actuel De L'avant-Arc Et De L'arc Du Coude De Arica Dans L'orogénèse Des Andes Centrales, Université Toulouse III - Paul Sabatier.

DAVIS, D., SUPPE, J. \& DAHLEN, F. (1983) Mechanics of Fold-and-Thrust Belts and Accretionary Wedges. Journal of Geophysical Research: Solid Earth (1978-2012), 88, 1153-1172.

DECOU, A., VON EYNATTEN, H., MAMANI, M., SEMPERE, T. \& WÖRNER, G. (2011) Cenozoic forearc basin sediments in Southern Peru (15-18 S): stratigraphic and heavy mineral constraints for Eocene to Miocene evolution of the Central Andes. Sedimentary Geology, 237, 55-72.

DECOU, A., VON EYNATTEN, H., DUNKL, I., FREI, D. \& WÖRNER, G. (2013) Late Eocene to Early Miocene Andean uplift inferred from detrital zircon fission track and U-Pb dating of Cenozoic forearc sediments (15-18 $\left.{ }^{\circ} \mathrm{S}\right)$. Journal of South American Earth Sciences, 45, 6-23.

DORBATH, L., CISTERNAS, A. \& DORBATH, C. (1990) Assessment of the size of large and great historical earthquakes in Peru. Bulletin of the Seismological Society of America, 80, 551-576.

EHLERS, T. A. \& POULSEN, C. J. (2009) Influence of Andean uplift on climate and paleoaltimetry estimates. Earth and Planetary Science Letters, 281, 238-248.

ENGLAND, P. C. \& HOLLAND, T. J. B. (1979) Archimedes and the Tauern eclogites: the role of buoyancy in the preservation of exotic eclogite blocks. Earth and Planetary Science Letters, 44, 287-294.

FARÍAS, M., CHARRIER, R., COMTE, D., MARTINOD, J. \& HÉRAIL, G. (2005) Late Cenozoic Deformation and Uplift of the Western Flank of the Altiplano: Evidence from the Depositional, Tectonic, and Geomorphologic Evolution and Shallow Seismic Activity (Northern Chile at 19 30' S). Tectonics, 24.

GARCIA, M., GARDEWEG, M., CLAVERO, J., HÉRAIL, G., Servicio Nacional de Geología y Minería. (2004) Hoja Arica, Región de Tarapacá. Carta Geológica de Chile, Serie Geología Básica, $1(250), 000$.

GARCIA, M. \& HÉRAIL, G. (2005) Fault-Related Folding, Drainage Network Evolution and Valley Incision During the Neogene in the Andean Precordillera of Northern Chile. Geomorphology, 65, 279-300.

GARCIA, M., RIQUELME, R., FARÍAS, M., HÉRAIL, G. \& CHARRIER, R. (2011) Late Miocene-Holocene

This article is protected by copyright. All rights reserved. 
Canyon Incision in the Western Altiplano, Northern Chile: Tectonic or Climatic Forcing? Journal of the Geological Society, 168, 1047-1060.

GARZIONE, C. N., MOLNAR, P., LIBARKIN, J. C. \& MACFADDEN, B. J. (2006) Rapid late Miocene rise of the Bolivian Altiplano: Evidence for removal of mantle lithosphere. Earth and Planetary Science Letters, 241, 543-556.

GARZIONE, C. N., MOLNAR, P., LIBARKIN, J. C. \& MACFADDEN, B. J. (2007). Reply to Comment on "Rapid late Miocene rise of the Bolivian Altiplano: Evidence for removal of mantle lithosphere" by Garzione et al.(2006), Earth Planet. Sci. Lett. 241 (2006) 543-556. Earth and Planetary Science Letters, 259, 630-633.

GARZIONE, C.N., HOKE, G.D., LIBARKIN, J.C., WITHERS, S., MACFADDEN, B., EILER, J., GHOSH, P. \& MULCH, A. (2008) Rise of the Andes. Science, 320, 1304-1307.

GARZIONE, C. N., AUERBACH, D. J., SMITH, J. J. S., ROSARIO, J. J., PASSEY, B. H., JORDAN, T. E. \& EILER, J. M. (2014) Clumped isotope evidence for diachronous surface cooling of the Altiplano and pulsed surface uplift of the Central Andes. Earth and Planetary Science Letters, 393, 173-181.

GEPHART, J.W. (1994) Topography and Subduction Geometry in the Central Andes: Clues to the Mechanics of a Noncollisional Orogen. Journal of Geophysical Research: Solid Earth (19782012), 99, 12279-12288.

GHOSH, P., GARZIONE, C. N. \& EILER, J. M. (2006) Rapid uplift of the Altiplano revealed through 13C180 bonds in paleosol carbonates. Science, 311, 511-515.

GONZÁLEZ, E. (1989) Hydrocarbon resources in the coastal zone of Chile. Geology of the Andes and its relation to hydrocarbon and mineral resources, 383-404.

GONZÁLEZ, G., CEMBRANO, J., CARRIZO, D., MACCI, A. \& SCHNEIDER, H. (2003) The Link between Forearc Tectonics and Pliocene-Quaternary Deformation of the Coastal Cordillera, Northern Chile. Journal of South American Earth Sciences, 16, 321-342.

GREGORY-WODZICKI, K.M. (2000) Uplift History of the Central and Northern Andes: A Review. Geological Society of America Bulletin, 112, 1091-1105.

HALL, S. R., FARBER, D. L., AUDIN, L. \& FINKEL, R. C. (2012) Recently active contractile deformation in the forearc of southern Peru. Earth and Planetary Science Letters, 337, 85-92.

HAMPEL, A. (2002) The Migration History of the Nazca Ridge Along the Peruvian Active Margin: A ReEvaluation. Earth and Planetary Science Letters, 203, 665-679.

HAMPEL, A., ADAM, J. \& KUKOWSKI, N. (2004) Response of the Tectonically Erosive South Peruvian Forearc to Subduction of the Nazca Ridge: Analysis of Three-Dimensional Analogue Experiments. Tectonics, 23.

HARTLEY, A.J., MAY, G., CHONG, G., TURNER, P., KAPE, S.J. \& JOLLEY, E.J. (2000) Development of a Continental Forearc: A Cenozoic Example from the Central Andes, Northern Chile. Geology, 28, 331-334.

HARTLEY, A. J. (2005) What caused Andean uplift. 6th ISAG. IRD, Barcelona, 824-827.

HARTLEY, A. J., SEMPÉRÉ, T. \& WÖRNER, G. (2007) A comment on "Rapid late Miocene rise of the Bolivian Altiplano: Evidence for removal of mantle lithosphere" by CN Garzione et al.[Earth Planet. Sci. Lett. 241 (2006) 543-556]. Earth and Planetary Science Letters, 259, 625-629.

HAYES, G.P., HERMAN, M.W., BARNHART, W.D., FURLONG, K.P., RIQUELME, S., BENZ, H.M., BERGMAN, E., BARRIENTOS, S., EARLE, P.S. \& SAMSONOV, S. (2014) Continuing Megathrust Earthquake Potential in Chile after the 2014 Iquique Earthquake. Nature, 512, 295-298.

HOKE, G. D., ISACKS, B. L., JORDAN, T. E., Blanco, N., TOMLINSON, A. J. \& RAMEZANI, J. (2007) Geomorphic evidence for post-10 Ma uplift of the western flank of the central Andes 18 30'22 S. Tectonics, 26.

IOC, IHO and BODC (2003) Centenary Edition of the GEBCO Digital Atlas, published on CD-ROM on behalf of the Intergovernmental Oceanographic Commission and the International Hydrographic Organization as part of the General Bathymetric Chart of the Oceans, British Oceanographic Data Centre, Liverpool, U.K.

This article is protected by copyright. All rights reserved. 
ISACKS, B.L. (1988) Uplift of the Central Andean Plateau and Bending of the Bolivian Orocline. Journal of Geophysical Research: Solid Earth (1978-2012), 93, 3211-3231.

JACAY, J., SEMPÉRÉ, T., HUSSON, L. \& PINO, A. (2002) Structural Characteristics of the Incapuquio Fault System, Southern Peru. Andean Geodynamics : extended abstracts, 319-321. ISAG International Symposium on Andean Geodynamics, 5, Toulouse (FRA).

JORDAN, T. E., BURNS, W. M., VEIGA, R., PÁNGARO, F., COPELAND, P., KELLEY, S. \& MPODOZIS, C. (2001) Extension and basin formation in the southern Andes caused by increased convergence rate: A mid-Cenozoic trigger for the Andes. Tectonics, 20, 308-324.

JORDAN, T., NESTER, P., BLANCO, N., HOKE, G., DAVILA, F. \& TOMLINSON, A. (2010) Uplift of the Altiplano-Puna Plateau: A View from the West. Tectonics, 29.

JORDAN, T.E., KIRK-LAWLOR, N.E., BLANCO, N., RECH, J.A. \& COSENTINO, N.J. (2014) Landscape Modification in Response to Repeated Onset of Hyperarid Paleoclimate States since $14 \mathrm{Ma}$, Atacama Desert, Chile. Geological Society of America Bulletin, B30978. 30971.

KENDRICK, E., BEVIS, M., SMALLEY, R. \& BROOKS, B. (2001) An integrated crustal velocity field for the central Andes. Geochemistry, Geophysics, Geosystems, 2.

KING, G. C., STEIN, R. S. \& RUNDLE, J. B. (1988) The growth of geological structures by repeated earthquakes 1. Conceptual framework. Journal of Geophysical Research: Solid Earth, 93, 13307-13318.

KIRK-LAWLOR, N. E., JORDAN, T. E., RECH, J. A. \& LEHMANN, S. B. (2013) Late Miocene to Early Pliocene paleohydrology and landscape evolution of Northern Chile, 19 to $20 \mathrm{~S}$. Palaeogeography, Palaeoclimatology, Palaeoecology, 387, 76-90.

KOBER, F., SCHLUNEGGER, F., ZEILINGER, G. \& SCHNEIDER, H. (2006) Surface Uplift and Climate Change: The Geomorphic Evolution of the Western Escarpment of the Andes of Northern Chile between the Miocene and Present. Geological Society of America Special Papers, 398, 75-86.

KUKOWSKI, N. \& ONCKEN, O. (2006) Subduction Erosion-the "Normal" Mode of Fore-Arc Material Transfer along the Chilean Margin?. The Andes, 217-236.

LAMB, S. \& DAVIS, P. (2003) Cenozoic Climate Change as a Possible Cause for the Rise of the Andes. Nature, 425, 792-797.

LAY, T., KANAMORI, H., AMMON, C. J., KOPER, K. D., HUTKO, A. R., YE, L., YUE, H. \& RUSHING, T. M. (2012) Depth-varying rupture properties of subduction zone megathrust faults. Journal of Geophysical Research: Solid Earth, 117.

LI, S., MORENO, M., BEDFORD, J., ROSENAU, M. \& ONCKEN, O. (2015) Revisiting viscoelastic effects on interseismic deformation and locking degree: A case study of the Peru-North Chile subduction zone, Journal of Geophysical Research: Solid Earth, 120, 4522-4538.

LIU, X., MCNALLY, K.C. \& SHEN, Z.K. (1995) Evidence for a Role of the Downgoing Slab in Earthquake Slip Partitioning at Oblique Subduction Zones. Journal of Geophysical Research: Solid Earth (1978-2012), 100, 15351-15372.

LOVELESS, J.P., ALLMENDINGER, R.W., PRITCHARD, M.E., GARROWAY, J.L. \& GONZÁLEZ, G. (2009) Surface Cracks Record Long-Term Seismic Segmentation of the Andean Margin. Geology, 37, 23-26.

LOVELESS, J.P., ALLMENDINGER, R.W., PRITCHARD, M.E. \& GONZÁLEZ, G. (2010) Normal and reverse faulting driven by the subduction zone earthquake cycle in the northern Chilean fore arc. Tectonics, 29.

MAKSYMOWICZ, A. (2015) The geometry of the Chilean continental wedge: Tectonic segmentation of subduction processes off Chile. Tectonophysics, 659, 183-196.

MANCKTELOW, N.S. (1995) Nonlithostatic pressure during sediment subduction and the development and exhumation of high pressure metamorphic rocks. Journal of Geophysical Research: Solid Earth (1978-2012), 100, 571-583.

MCQUARRIE, N. (2002) Initial plate geometry, shortening variations, and evolution of the Bolivian orocline. Geology, 30, 867-870.

This article is protected by copyright. All rights reserved. 
MELNICK, D. (2016) Rise of the central Andean coast by earthquakes straddling the Moho. Nature Geoscience, 9,401-407

MÉTOIS, M., VIGNY, C., \& SOCQUET, A. (2016) Interseismic Coupling, Megathrust Earthquakes and Seismic Swarms Along the Chilean Subduction Zone $\left(38^{\circ}-18^{\circ} \mathrm{S}\right)$. Pure and Applied Geophysics, 173, 1431-1449.

NESTER, P. \& JORDAN, T. (2012) The Pampa Del Tamarugal Forearc Basin in Northern Chile: The Interaction of Tectonics and Climate. Tectonics of Sedimentary Basins: Recent Advances, 369-381.

NORTON, K. \& SCHLUNEGGER, F. (2011) Migrating Deformation in the Central Andes from Enhanced Orographic Rainfall. Nature communications, 2, 584.

ONCKEN, O., HINDLE, D., KLEY, J., ELGER, K., VICTOR, P. \& SCHEMMANN, K. (2006) Deformation of the central Andean upper plate system-Facts, fiction, and constraints for plateau models. In The Andes (3-27). Springer Berlin Heidelberg.

ORTLIEB, L., ZAZO, C., GOY, J., HILLAIRE-MARCEL, C., GHALEB, B. \& COURNOYER, L. (1996) Coastal deformation and sea-level changes in the northern Chile subduction area (23 S) during the last 330 ky. Quaternary Science Reviews, 15, 819-831.

PINTO, L., HÉRAIL, G. \& CHARRIER, R. (2004) Sedimentación sintectónica asociada a las estructuras neógenas en la Precordillera de la zona de Moquella, Tarapacá ( $19^{\circ} 15^{\prime} \mathrm{S}$, norte de Chile). Revista geológica de Chile, 31, 19-44.

REGARD, V., SAILLARD, M., MARTINOD, J., AUDIN, L., CARRETIER, S., PEDOJA, K., RIQUELME, R., PAREDES, P. \& HÉRAIL, G. (2010) Renewed Uplift of the Central Andes Forearc Revealed by Coastal Evolution During the Quaternary. Earth and Planetary Science Letters, 297, 199-210.

ROBINSON, D.P., DAS, S. \& WATTS, A.B. (2006) Earthquake rupture stalled by a subducting fracture zone. Science, 312, 1203-1205.

ROPERCH, P., SEMPÉRÉ, T., MACEDO, O., ARRIAGADA, C., FORNARI, M., TAPIA, C., GARCIA, M. \& LAJ, C. (2006) Counterclockwise Rotation of Late Eocene-Oligocene Fore-Arc Deposits in Southern Peru and Its Significance for Oroclinal Bending in the Central Andes. Tectonics, 25.

RUFF, L.J. (1989) Do trench sediments affect great earthquake occurrence in subduction zones?. In Subduction Zones Part II (263-282).

SAVAGE, J.C. (1983) A dislocation model of strain accumulation and release at a subduction zone. Journal of Geophysical Research: Solid Earth, 88, 4984-4996.

SCHILDGEN, T.F., HODGES, K.V., WHIPPLE, K.X., REINERS, P.W. \& PRINGLE, M.S. (2007) Uplift of the Western Margin of the Andean Plateau Revealed from Canyon Incision History, Southern Peru. Geology, 35, 523-526.

SCHILDGEN, T.F., HODGES, K.V., WHIPPLE, K.X., PRINGLE, M.S., VAN SOEST, M. \& CORNELL, K. (2009) Late Cenozoic structural and tectonic development of the western margin of the central Andean Plateau in southwest Peru. Tectonics, 28.

SCHLUNEGGER, F., KOBER, F., ZEILINGER, G. \& VON ROTZ, R. (2010) Sedimentology-Based Reconstructions of Paleoclimate Changes in the Central Andes in Response to the Uplift of the Andes, Arica Region between 19 and $21 \mathrm{~S}$ Latitude, Northern Chile. International Journal of Earth Sciences, 99, 123-137.

SCHWELLER, W.J., KULM, L.D., \& PRINCE, R.A. (1981) Tectonics, structure, and sedimentary framework of the Peru-Chile trench. Geological Society of America Memoirs, 154, 323-350.

SHREVE, R.L., \& CLOOS, M. (1986) Dynamics of sediment subduction, melange formation, and prism accretion. Journal of Geophysical Research: Solid Earth (1978-2012), 91, 10229-10245.

SEMPÉRÉ, T., HARTLEY, A. \& ROPERCH, P. (2006) Comment on" Rapid Uplift of the Altiplano Revealed Through 13C-180 Bonds in Paleosol Carbonates". Science, 314, 760-760.

SZÉKELY, B., KOMA, Z., KARÁTSON, D., DORNINGER, P., WÖRNER, G., BRANDMEIER, M., \& NOTHEGGER, C. (2014) Automated recognition of quasi-planar ignimbrite sheets as paleosurfaces via robust segmentation of digital elevation models: an example from the Central Andes. Earth Surface Processes and Landforms, 39, 1386-1399.

This article is protected by copyright. All rights reserved. 
THATCHER, W. (1989) Earthquake recurrence and risk assessment in circum-Pacific seismic gaps. Nature, 341, 432-434.

THOURET, J.C., WÖRNER, G., GUNNELL, Y., SINGER, B., ZHANG, X. \& SOURIOT, T. (2007). Geochronologic and stratigraphic constraints on canyon incision and Miocene uplift of the Central Andes in Peru. Earth and Planetary Science Letters, 263, 151-166.

TOSDAL, R.M., CLARK, A.H. \& FARRAR, E. (1984) Cenozoic Polyphase Landscape and Tectonic Evolution of the Cordillera Occidental, Southernmost Peru. Geological Society of America Bulletin, 95, 1318-1332.

UHLIG, D. (1999) Die Westabdachung der Zentralanden in den Provinzen Arica und Parinacota, Nordchile: Landschaftsentwicklung und Geologie. University of Stuttgart, Profil 17, 167-244.

VICTOR, P., ONCKEN, O. \& GLODNY, J. (2004) Uplift of the western Altiplano plateau: Evidence from the Precordillera between 20 and $21 \mathrm{~S}$ (northern Chile). Tectonics, 23.

VICTOR, P., SOBESIAK, M., GLODNY, J., NIELSEN, S.N. \& ONCKEN, O. (2011) Long-term persistence of subduction earthquake segment boundaries: evidence from Mejillones Peninsula, northern Chile. Journal of Geophysical Research: Solid Earth, 116.

VON HUENE, R., WEINREBE, W. \& HEEREN, F. (1999) Subduction erosion along the North Chile margin. Journal of geodynamics, 27, 345-358.

VON HUENE, R. \& RANERO, C.R. (2003) Subduction erosion and basal friction along the sediment-starved convergent margin off Antofagasta, Chile. Journal of Geophysical Research: Solid Earth, 108.

VON ROTZ, R., SCHLUNEGGER, F., HELLER, F. \& VILLA, I. (2005) Assessing the Age of Relief Growth in the Andes of Northern Chile: Magneto-Polarity Chronologies from Neogene Continental Sections. Terra Nova, 17, 462-471.

WANG, K. \& DIXON, T. (2004) "Coupling" semantics and science in earthquake research. EOS, Transactions American geophysical Union, 85, 180-180.

WHIPPLE, K.X. \& GASPARINI, N.M. (2014) Tectonic control of topography, rainfall patterns, and erosion during rapid post-12 Ma uplift of the Bolivian Andes. Lithosphere, 6, 251-268.

WIPF, M., ZEILINGER, G., SEWARD, D. \& SCHLUNEGGER, F. (2008) Focused Subaerial Erosion During Ridge Subduction: Impact on the Geomorphology in South-Central Peru. Terra Nova, 20, 110.

WÖRNER, G., HARMON, R.S., DAVIDSON, J., MOORBATH, S., TURNER, D.L., MCMILLAN, N., NYES, C., LOPEZ-ESCOBAR, L. \& MORENO, H. (1988) The Nevados de Payachata volcanic region (18 S/69 W, N. Chile). Bulletin of Volcanology, 50, 287-303.

WÖRNER, G., UHLIG, D., KOHLER, I. \& SEYFRIED, H. (2002) Evolution of the West Andean Escarpment at $18 \mathrm{~S}$ (N. Chile) During the Last $25 \mathrm{Ma}$ : Uplift, Erosion and Collapse through Time. Tectonophysics, 345, 183-198.

WOTZLAW, J.F., DECOU, A., VON EYNATTEN, H., WÖRNER, G. \& FREI, D. (2011) Jurassic to Palaeogene tectono-magmatic evolution of northern Chile and adjacent Bolivia from detrital zircon U-Pb geochronology and heavy mineral provenance. Terra Nova, 23, 399-406.

ZEILINGER, G., SCHLUNEGGER, F. \& SIMPSON, G. (2005) The Oxaya Anticline (Northern Chile): A Buckle Enhanced by River Incision? Terra Nova, 17, 368-375.

This article is protected by copyright. All rights reserved. 


\section{TABLE AND FIGURE CAPTIONS}

Table 1 - Estimates of post-Miocene eroded volumes for three different diameters of sampling window. Left - right corresponds to North - South.

Figure 1 - Topographic map of the Western Central Andean subduction zone. The main subaerial and submarine channels are highlighted, as well as the main towns, the Coastal Cordillera and the main topographic features of the subducting plate. The range of trench marked as "orthogonal" represents the segment where the obliquity of convergence does not exceed $10^{\circ}$. Both submarine and subaerial topographies have been extrapolated from the 1 km-resolution GEBCO Digital Elevation Model (IOC, IHO and BODC, 2003). The alongstrike pattern of post-10 Ma sediment discharge has been estimated through the subtraction of the modern topography to the interpolated late Miocene pediplain (see text for details). The macro-catchments considered for these estimates are bound by black solid lines. The rivers Ocoña, Camana, Vitor (Peru) and Loa (Chile) have been excluded because they extend too far beyond the Western Cordillera, where the paleo-topography cannot be well-constrained. The ideal tracks of the profiles shown in Fig.3 are also displayed. Convergence vector after Li et al. (2015). CC: Coastal Cordillera, CD: Central Depression, PC: Precordillera, WC: Western Cordillera.

Figure 2 - Swath profiles along the axis of the Coastal Cordillera (a) and across the forearc of the Western Central Andes in southern Peru (b), at the Arica Bend (c) and in northern Chile (d). The topographic expression of the uplifted Coastal Cordillera in southern Peru and northern Chile, highlighted by the occurrence of a steep coastal scarp, strongly differs from the gentle slopes of the Arica Bend. The offshore forearc slope angle $\alpha$ has been calculated along each margin-perpendicular swath profile. The displayed values of $\alpha$ represent the average of the maximum and minimum steepness of the forearc comprised within the trench and the shelf-break (black arrows). Swath band-width (a) $10 \mathrm{~km}$, (b,c,d) $50 \mathrm{~km}$; swath smoothing length (a) $2 \mathrm{~km}$, (b,c,d) $5 \mathrm{~km}$; VE vertical exaggeration; CC Coastal Cordillera; CD Central Depression; PC Precordillera; WC Western Cordillera.

Figure 3 - Qualitative cross sections of the coastal margins in southern Peru (a), at the Arica Bend (b) and in northern Chile (c). In (a) and (c) the Coastal Cordillera constitutes a sediment barrier that separates marine from continental environments. In (b) the absence of the Coastal Cordillera allows the volcanoclastic deposits to reach the marine environment. The ideal location of these profiles is shown in Figure 1. CC: Coastal Cordillera, CD: Central Depression, Cam: Camana formation, Moq: Moquegua formation, Az: Azapa formation, Ox: Oxaya formation, ED: El Diablo formation, LS: lake sediments / salar.

Figure 4 - Simplified structural map of the study area compiled from our own observations and from the literature (González et al., 2003; Garcia et al., 2004; Audin et al., 2006; David, 2007; Audin et al., 2008; Allmendinger \& González, 2010; Garcia et al., 2011). The seismicity contour lines represent the number of $M>4$ earthquakes found within an area of 15

This article is protected by copyright. All rights reserved. 
$\mathrm{km}$ radius, and have been extrapolated from the ANSS Comprehensive Catalog (December 2014) and from the literature (Comte \& Pardo, 1991). Most of the seismic activity currently coincides with the areas located above the locked plate boundary and with the recent volcanic arc. More details on the structures shown in this figure are available in the results section and referred to the circled letters from "a" to "i". The top-left corner displays the location of the Gephart Symmetry Plane at the orogeny scale (Gephart, 1994).

Figure 5 - (a) Center - Satellite image of the Central Depression between rivers Azapa and Camarones. The Coastal Cordillera is highlighted in red, and the lineaments that form the northern termination of the Humayani flexure are shown with white dashed lines (Garcia et al., 2011). (b) Top left - The drainage network shows a preferred orientation along the direction of the structures. (c) Top right - Sharp change in color denotes that westward fan progradation has been interrupted by slope inversion along a minor blind fault. (d) Bottom Local drainage reorganization along NW-SE oriented lineaments is evidenced by cross-cut relationships with the abandoned reach (black dashed line), which also seems to have been incised deeper due to localized uplift of the area comprised within the white dashed lines. Imagery source: Esri, DigitalGlobe, geoEye, Earthstar Geographics, CNES/Airbus DS,USDA, USGS, AEX, Getmapping, Aerogrid, IGN, IGP, Swisstopo, and the GIS User Community.

Figure 6 - Summary of the observed characteristics of the Peru-Chile trench between $17^{\circ}$ $22^{\circ}$ S. (a) Modern trench fill thickness after Schweller et al. (1981). (b) Post-10 Ma pattern of cumulative sediment supply to the trench according to our estimates (Table 1). The black columns are located in the middle of the latitudinal range of each macro-catchment (Fig.1). (c) Mean elevation of the coast (20 km wide swath profile). In order to compensate for the curvature of the margin, the latitude along this profile has been projected to the trench along the convergence direction. (d) Subduction obliquity, the values represent the divergence between the margin-perpendicular and the convergence vector. (e) Latitudinal range of the subducting topographic features along the trench, according to Contreras-Reyes \& Carrizo (2011) and Robinson et al. (2006), NFZ: Nazca Fault Zone. (f) Mean earthquake density between the trench and the coast. The values represent the number of $M>4$ earthquakes found within a $15 \mathrm{~km}$ radius window.

Figure 7 - Qualitative cross sections of the Western Central Andean forearc showing the feedback mechanisms discussed in the text. (a) At e.g. $19.5^{\circ} \mathrm{S}$, full seismic coupling causes relevant lower-crustal thickening and coastal uplift. The uplifting Coastal Cordillera dams the drainage, inducing continental sedimentation and sediment starvation in the trench. A positive feedback is thus triggered. (b) At $18.3^{\circ} \mathrm{S}$ (Arica Bend), a sediment-thickened subduction channel lowers seismic coupling, which in turn induces little or no thickening and no uplift. The resulting absence of the Coastal Cordillera keeps the drainage open, triggering positive feedback contrasting to the situation in (a). Modified from González et al. (2003) and Lamb and Davis (2003).

This article is protected by copyright. All rights reserved. 
Figure 8 - Schematic evolution of the Arica Bend. The convergence vectors are indicated after McQuarrie (2002) and Li et al. (2015). (a) Before $25 \mathrm{Ma}$. The incipient margin curvature induces trench-parallel extension at its apex in the forearc and trench-parallel compression along the limbs north and south of it. (b) Between 25 and 10 Ma. The erosional and volcanic products of the growing Andes are deposited in the Central Depression, where the uplifting Coastal Cordillera acts as a barrier. Relative subsidence due to extension at the curvature apex allows the supplied sediments to reach the submarine realm and possibly initiate the feedback mechanisms shown in Figure 7. (c) Between 10 and 3 Ma. As volcanoclastic sedimentation ceases, perennial streams carve the deep canyons of the Western Central Andes. Thanks to the shape of the forearc, channel incision converges into the Arica Bend, where the eroded volume of sediments exceeds the accommodation space of the offshore basins and reaches the trench. Convergence of the submarine mass-wasting processes also contributes to focused sedimentation offshore the Arica Bend. In contrary, the curvature limbs yield lower volumes of sediments, which also do not seem to reach over the offshore basins (grey shading). This pattern of trench sedimentation favors the persistence of the feedback mechanisms (Fig.7) although the area of low coastal uplift is offset from the apex of the margin curvature.

\begin{tabular}{|c|c|c|c|c|}
\hline Macro-catchment & Tambo & Ilo & Arica Bend & Tana \\
\hline \multirow{2}{*}{ Coordinates of mouth } & $17.17^{\circ} \mathrm{S}$ & $17.75^{\circ} \mathrm{S}$ & $18.40^{\circ} \mathrm{S}$ & $19.55^{\circ} \mathrm{S}$ \\
\hline & $71.82^{\circ} \mathrm{W}$ & $71.10^{\circ} \mathrm{W}$ & $70.40^{\circ} \mathrm{W}$ & $70.20^{\circ} \mathrm{W}$ \\
\hline Er. vol. $\left[\mathrm{km}^{3}\right] \mathrm{d}=5 \mathrm{~km}$ & 4083 & 2866 & 6900 & 803 \\
\hline Er. vol. $\left[\mathrm{km}^{3}\right] \mathrm{d}=7.5 \mathrm{~km}$ & 5286 & 3808 & 9134 & 1070 \\
\hline Er. vol. $\left[\mathrm{km}^{3}\right] \mathrm{d}=10 \mathrm{~km}$ & 6274 & 4624 & 11153 & 1320 \\
\hline
\end{tabular}

This article is protected by copyright. All rights reserved. 


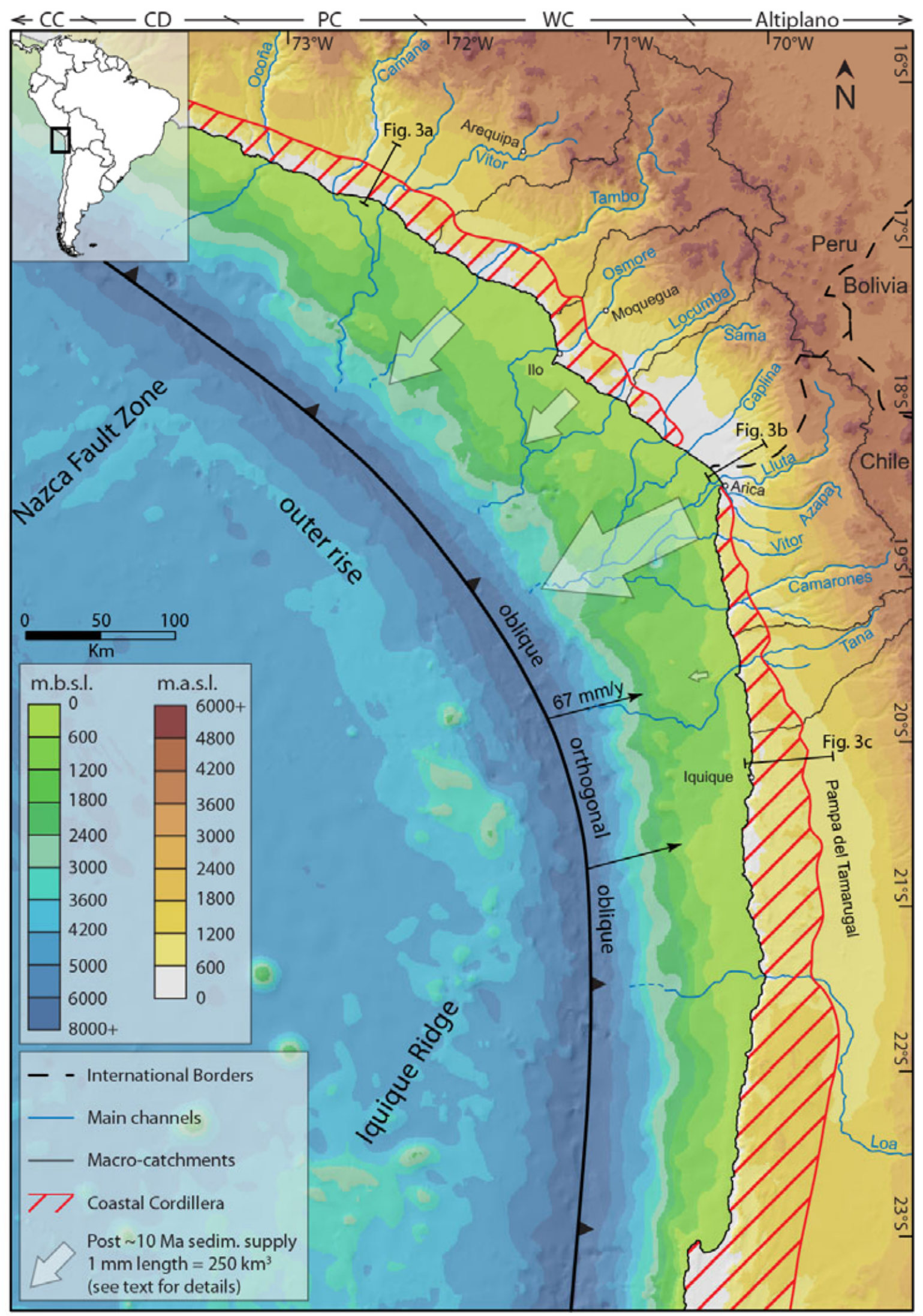

This article is protected by copyright. All rights reserved. 

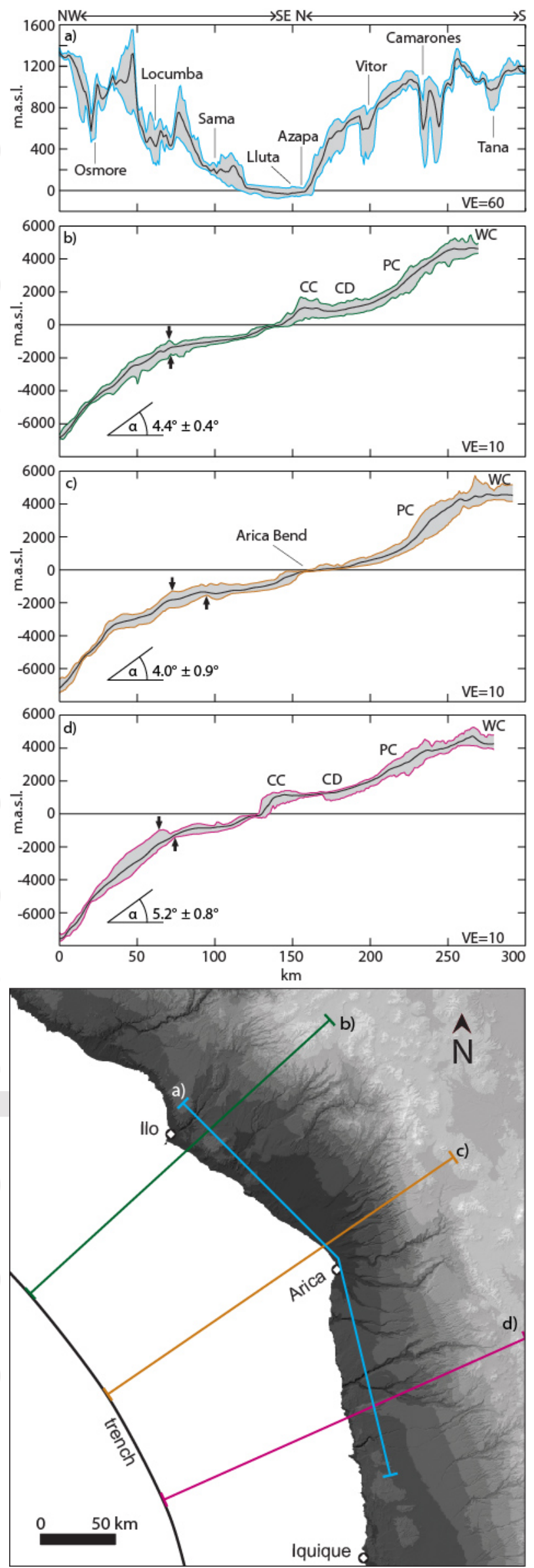

This article is protected by copyright. All rights reserved. 
a)

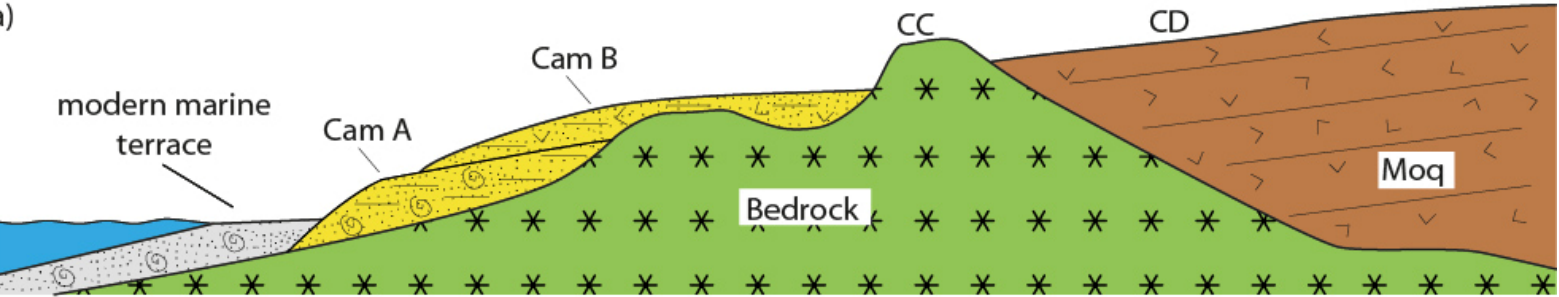

b)

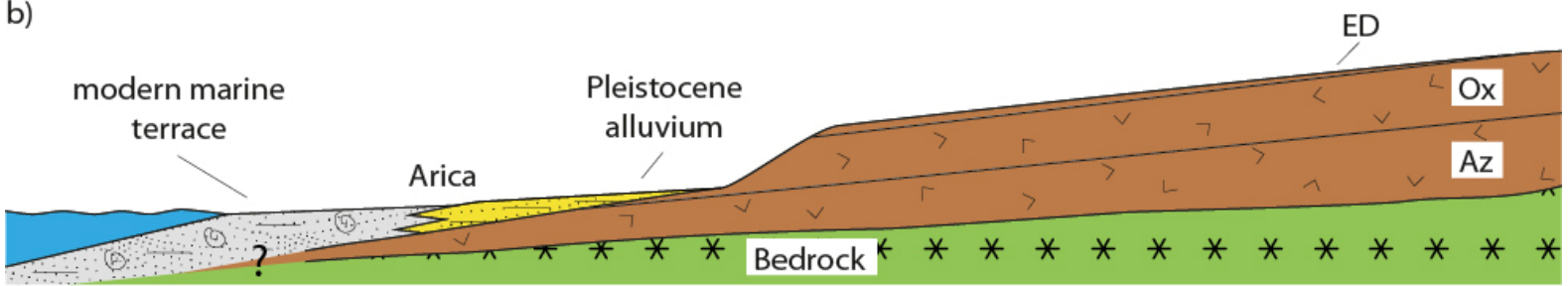

c)

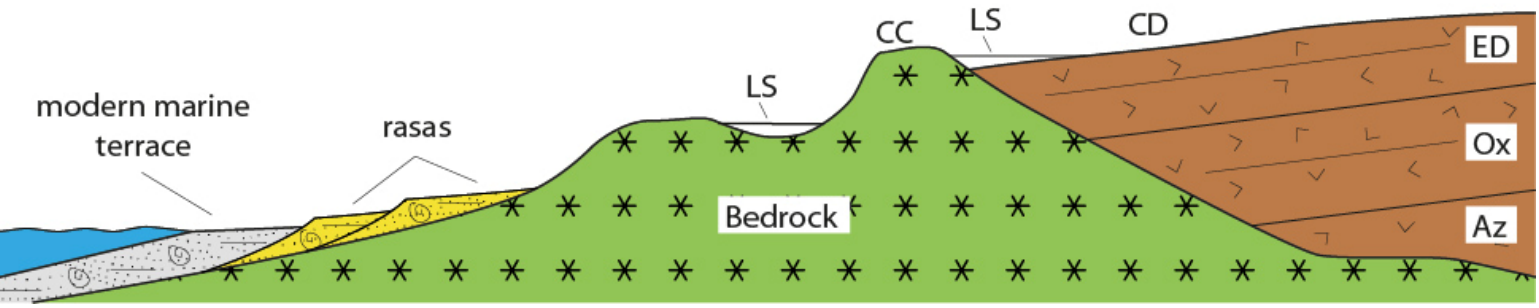

This article is protected by copyright. All rights reserved. 


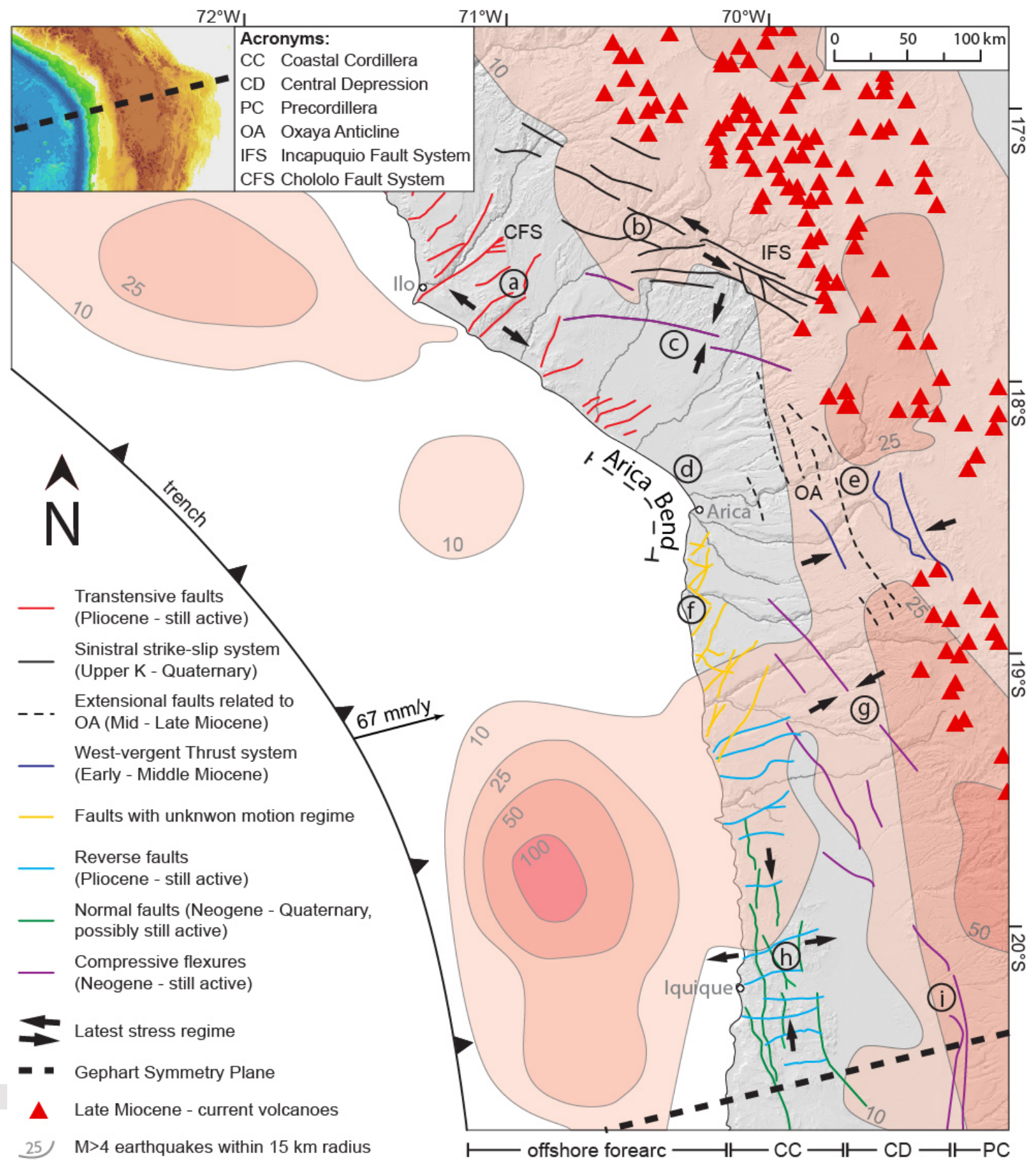

This article is protected by copyright. All rights reserved. 

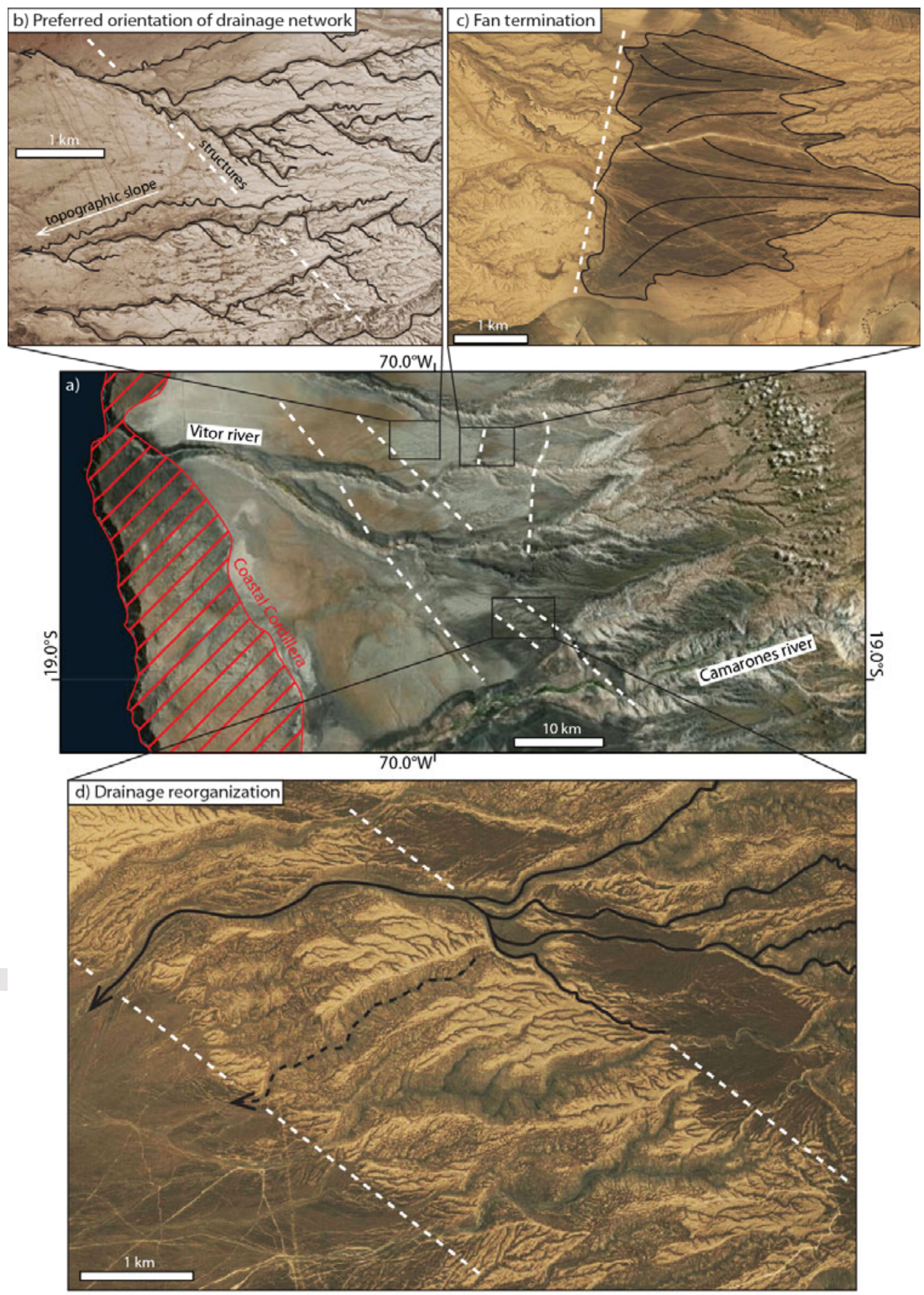

This article is protected by copyright. All rights reserved. 
Latitude

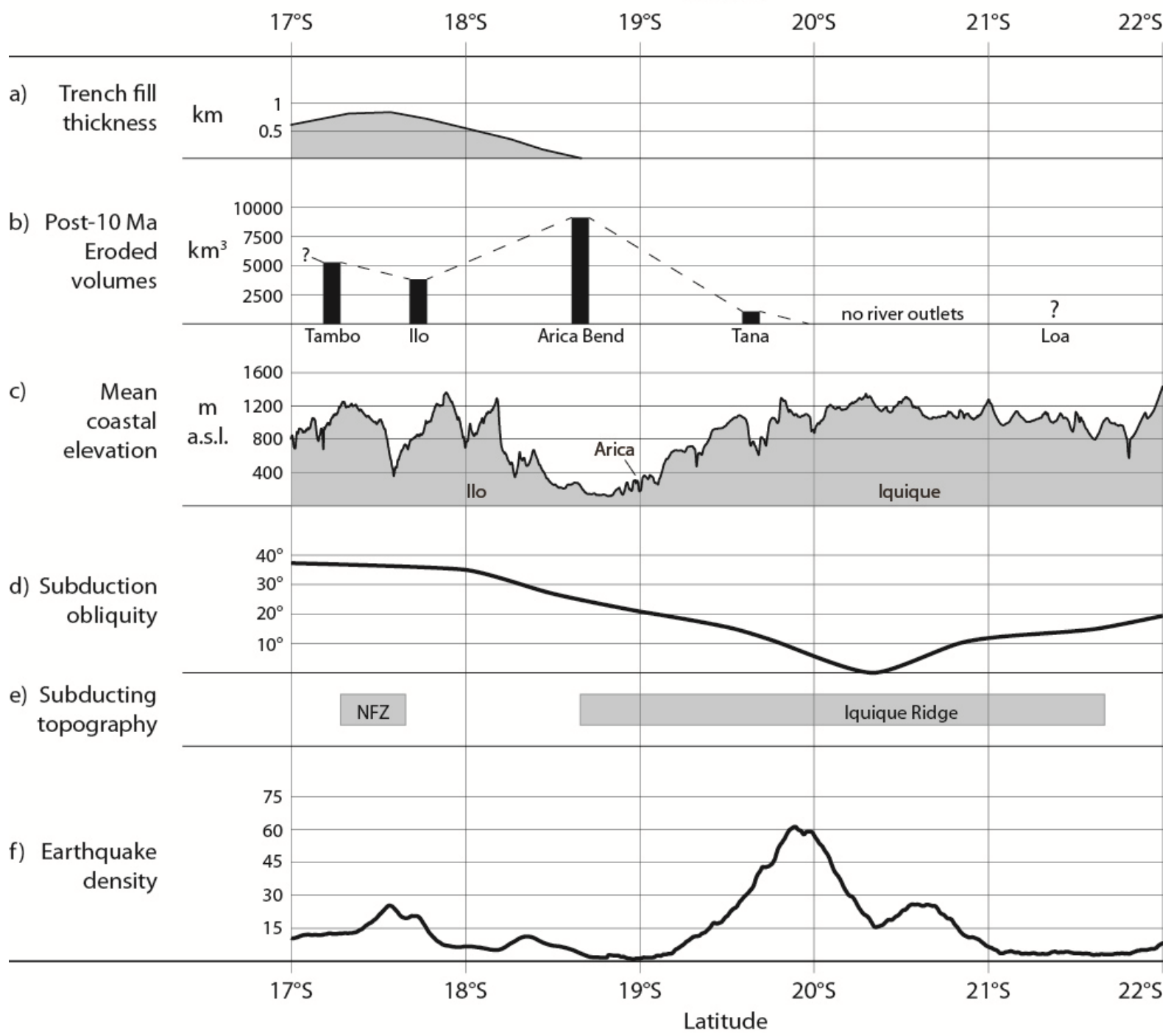

This article is protected by copyright. All rights reserved. 

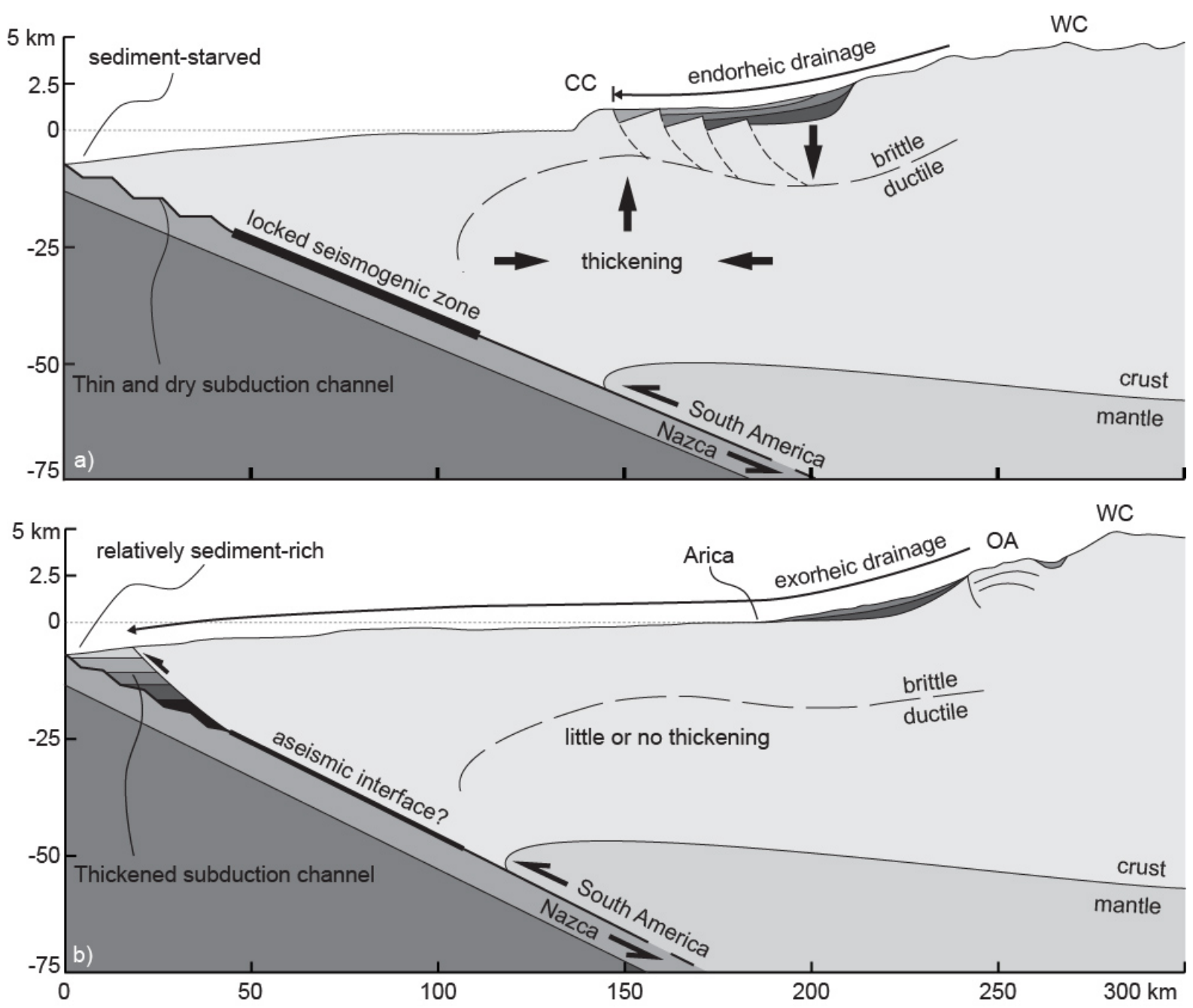

This article is protected by copyright. All rights reserved. 


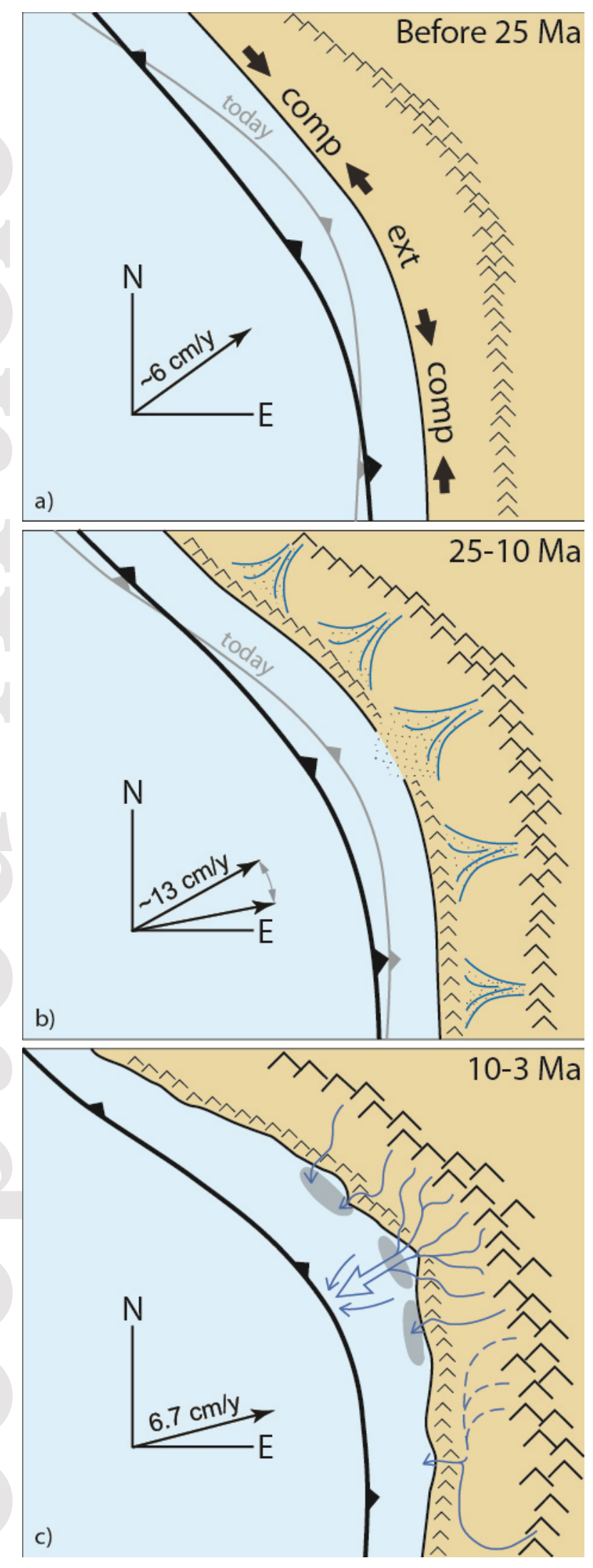

This article is protected by copyright. All rights reserved. 